OLE NORRBACK

\title{
Varför syns inte nordisk TV i nordbornas TV-apparater?
}

En rapport om nordiskt TV-samarbete

Sakkunniga och sekreterare

JUKKA LIEDES OCh ANNA VUOPALA

TEMANORD 2004:527 
Varför syns inte Nordisk TV i Nordbornas tv-apparater?

En rapport om nordiskt TV-samarbete

utarbetad av utredningsman Ole Norrback med Jukka Liedes

och Anna Vuopala som sakkunniga och sekreterare

ANP 2004:527

(C) Nordiska ministerrådet, Köpenhamn 2004

ISBN 92-893-1014-6

Tryck: Akaprint as, Århus 2004

Formgivning: Kjell Olsson - NMR / PUB

Upplaga: 400

Tryckt på miljövänligt papper som uppfyller kraven

i den nordiska miljösvanemärkningen.

Printed in Denmark

Säljes genom Nordiska ministerrådets agenter, se förteckning på sid 64 .

Fler publikationer från Nordiska rådet och ministerrådet

på www.norden.org/publikationer

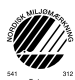

Nordiska ministerrådet

Store Strandstræde 18

DK-1255 Köpenhamn K

Telefon (+45) 33960200

Telefax (+45) 33960202

www.norden.org

\section{Det nordiska kultur-}

och massmediasamarbetet

Styrningsgruppen för nordiska kul-

tur- och massmediasamarbetet har

som uppgift att följa utvecklingen

på massmediaområdet i Norden

och internationellt samt att verka

för nordiskt samarbete och koordi-

nation på det mediapolitiska områ

det, såväl inom Norden som i för-

hållande till internationella organ.

Styrningsgruppen är ett rådgivande

organ för Nordiska ministerrådet $i$

kultur- och mediapolitiska frågor.

\section{Nordiska rådet}

Store Strandstræde 18

DK-1255 Köpenhamn K

Telefon (+45) 33960400

Telefax (+45) 33111870

\section{Nordiska ministerrådet}

inrättades 1971 som ett samar-

betsorgan mellan de nordiska län-

dernas regeringar. Ministerrådet

lägger fram förslag till Nordiska

rådets sessioner, vidarebefordrar

rådets rekommendationer, rappor-

terar till Nordiska rådet om sam-

arbetets resultat samt leder i sista

hand arbetet inom olika sektorer.

Statsministrarna har ett överordnat

ansvar för samarbetet, som i övrigt

koordineras av samarbetsminis-

trarna och den nordiska samarbets-

kommittén. Ministerrådet samman-

träder i olika sammansättningar

beroende på vilka frågor som skall

behandlas.

\section{Nordiska rådet}

bildades 1952 som ett samarbetsorgan mellan parlamenten och regeringarna i Danmark, Island, Norge och Sverige. Finland anslöt sig 1955. Färöarnas, Grönlands och Ålands delegationer ingår i Danmarks respektive Finlands delegationer. Rådet består av 87 valda medlemmar (parlamentsledamöter). Nordiska rådet är initiativtagare och rådgivande samt har kontrollerande och pådrivande uppgifter i det nordiska samarbetet. Nordiska rådets organ är plenarförsamlingen, presidiet och utskotten. 


\section{Förord}

TV-frågorna har länge haft en hög prioritet $\mathrm{i}$ det nordiska samarbetet. I relation till uppmärksam-heten i debatten och till förväntningarna är resultaten små. Också om TV-samarbetet ger resultat så har program från andra nordiska länder ingen framträdande position i många nordbors TV-tittande.

Uppdraget att utreda samarbetets nya förutsättningar som en följd av digitaliseringen har naturligtvis varit utmanande. Länge var jag tveksam till möjligheten att finna nya realiserbara förslag. Kombinationen av förväntningarna hos många nordbor, public service företagens ansträngda ekonomi, rättsinnehavarnas krav och teknikens nya möjligheter är så komplicerad och delvis motstridig att slutsatser, som kan få bredare stöd, inte är lätta att dra.

Den kulturpolitiska aspekten har varit viktig under arbetet med rapporten. Public service-bolagen har ett större kulturpolitiskt ansvar, redan p.g.a. sättet att finansiera verksamheten, än vad de kommersiella företagen i branschen har. Rapportens förslag bygger på tanken att mera samarbete ger mera och bättre programutbud. Samarbetet är speciellt viktigt för att program gjorda på basis av nordiska kultur- och samhällsvärderingar skall kunna hävda sig i konkurrens med program där våld, förenklingar, den starkes rätt och orättvisa rollmönster är dominerande. Detta gäller alldeles särskilt program avsedda för barn och ungdom.

I de nordiska kabelnäten finns TV-kanaler på engelska, tyska, italienska, franska, spanska, arabiska och på andra språk, men de nordiska kanalerna lyser ofta med sin frånvaro också i stora tätorter. Kan det möjligen bero på dålig marknadsföring? Kvalitetsmässigt kan de nordiska Tv-kanalerna mycket väl tävla med det utbud som finns i kabelnäten. 
Finansieringen av ett utökat samarbete är naturligtvis en svår fråga. Om licensbetalare i ett land inte vill stå för kostnaderna när programmen sänds i grannländerna, och om de får grannländernas program i utbyte, kan man naturligtvis ta avgift av tittarna $i$ grannländerna med hjälp av teknik som idag står till buds.

Public service-bolagen är fortfarande mycket nationella i sitt agerande, också när det gäller pro-grampolitiken. Nationell kultur och nordiska värderingar kan bäst försvaras i samarbete med likatänkande och med aktivitet också utanför landets gränser.

Uppdraget har varit intressant och jag vill tacka ministerrådet för förtroendet. Jag vill också tacka direktör Jukka Liedes för hans ovärderliga arbete, baserat på en bred sakkunskap och vicehäradshövding Anna Vuopala för hennes goda förmåga att samla material, organisera och formulera.

Helsingfors 30 december 2003

Ole Norrback 


\section{Innehåll}

Forord 3

Indhold 5

$1 \quad$ Indledning 7

2 Mandatet 9

2.1 Syftet med utredningen 9

2.2 Bakgrund till utredningen 10

3 Nuläget 11

3.1 Mottagningen av grannlands-Tv i Norden 11

3.2 Övrigt nordiskt radio- och televisionssamarbete 14

4 Medieutvecklingens ramvillkor och den audiovisuella politiken inom EU 17

5 Utvecklingen av digital tv och public service 21

5.1 Tekniska framsteg inom televisionsverksamheten 21

5.2 Reglering och finansiering av public service-företag i Norden 26

5.3 Marknaden, public service-verksamhetens framtid, konkurrensfrågorna 31

6 Grundprinciperna för de upphovsrättsliga lösningarna

6.1 Allmänt 34

6.2 Nuvarande lösning i Norden 36

6.3 En annan möjlighet 38

6.4 Satellit-och kabeldirektivet 40

7 Tekniska lösningsmodeller 42

8 Ställningstaganden och förslag till lösningar

8.1 Norden som en tv-hemmamarknad 49

8.2 Finansieringen av verksamheten 50

8.3 Mottagning/spridning av nordiska TV-program 51

8.4 Nordiskt programsamarbete 59

8.5 Public service - dess framtid och finansiering 60

8.6 Ett par problem 61

Källförteckning 62 



\section{Inledning}

Norden håller starkt samman delvis på grund av språkliga och kulturella likheter. Ett mycket viktigt instrument för såväl språklig som kulturell förståelse är möjligheten att se varandras public service-kanaler. Dessutom bygger en betydlig del av vår samhörighet på samarbete inom olika områden, bl.a. det nordiska radio- och televisionssamarbetet.

Frågan om grannlands-TV är mera än bara en angelägenhet för folk som bor i gränsbygder eller för språkliga minoriteter i respektive land. Det är frågan om att möjliggöra ett mångsidigt kulturutbyte de nordiska länderna emellan. Det politiska minimikravet för framtiden måste vara att de nuvarande möjligheterna att se grannländernas TV-kanaler bibehålls. Målet borde i princip vara att varje nordbo har möjlighet att följa de andra skandinaviska ländernas public service-programutbud.

I enlighet med Nordiska rådets medlemsförslag (A/1244/nord) skall Norden säkerställa fortsatt grannlands-Tv i samband med övergången till digitala sändningar och använda den nya tekniken till ökad distribution av public service-Tv.

För att man i de nordiska länderna skall kunna ta del av grannlandsteveutbudet förutsätter det att en hel del tekniska, ekonomiska och rättsliga frågor finner sin lösning.

Idén om ett gemensamt TV-område är inte bara en nordisk, utan även en europeisk tanke. Inom Europeiska gemenskapen gavs redan år 1989 ett direktiv om gränsöverskridande television. Inom EU har man konstaterat att en inre marknad för TV-tjänster dock inte ännu helt genomförts i enlighet med direktivet. Skälen för detta har bl.a. varit skillnaderna i de tekniska standarderna och marknadsstrukturen rörande sändningsrättigheterna. I rapporten behandlas kort förutom nordiska aspekter även den relevanta lagstiftningen och läget inom $\mathrm{EU}$. 
Även det finländska regeringensprogrammet innehåller ett uttalande enligt vilken "regeringen anser det vara viktigt att de nordiska televisionsprogrammens sebarhet tryggas«. 


\section{Mandatet}

\subsection{Syftet med utredningen}

Nordiska ministerrådet gav ambassadör Ole Norrback ett mandat att utreda och komma med förslag till hur tillgången till de övriga nordiska ländernas televisionsutbud kunde ordnas. Utredningen skall koncentrera sig på den digitala tekniken i framtiden, särskilt i den situation då de analoga sändningarna frångås.

Enligt mandatet skall efterfrågan på nordisk public service bedömas i ljuset av de aktuella möjligheterna att se grannländernas TV-kanaler.

Utredningen skall även behandla de för- och nackdelar av ett ökat utbud av grannlands-Tv som är förknippade med olika tekniska lösningar - digitala markbundna sändningar, kabelspridning och satellitdistribution. Dessutom skall utredningen bedöma de ekonomiska konsekvenserna av dessa distributionsmöjligheter.

Problemen av rättighetsmässig, teknisk och ekonomisk karaktär kommer att behandlas separat.

I utredningen granskas också hur utbudet av grannlands-Tv kan finansieras. I samband med granskningen bedöms frågan om man skall acceptera betalning per mottagare, eller om utbudet skall vara en sådan gratis tjänst till medborgarna som betalas av staterna, företagen tillsammans eller någon annan finansiär.

Som utgångspunkt för utredningen tas de redogörelser som har utarbetats av MR-K och styrningsgruppen för nordiskt kultur- och mediesamarbete.

Rapporten skall ge förslag till lösningar på frågor om grannlands-TV på ett allmännordiskt plan. Specialarrangemangen mellan Sverige och Finland behandlas separat. Problemställningarna granskas ur olika infallsvinklar, bl.a. den kulturpolitiska. 


\subsection{Bakgrund till utredningen}

Både Nordiska rådet och Nordiska ministerrådet har utarbetat rapporter om det nordiska $\mathrm{TV}$-samarbetet under de senaste åren. Frågan har också varit framme mycket $i$ den allmänna diskussionen under den senaste tiden p.g.a. den tekniska utvecklingen - mediekonvergensen inkluderad - som i många avseenden ger flera nya möjligheter men ibland också kan förorsaka problem.

Denna utredning bygger på rapporter från MR-K och styrningsgruppen för nordiskt kultur- och mediesamarbete, särskilt rapporterna "Public service i Norden", del I och II. Dessutom har en stor del av frågeställningarna i den senaste utredningen "Grannlands-TV vid övergången till digitala sändningar « från oktober 2001 använts som bakgrund till ställningstagandena i denna utredning. Utredningar om medieutvecklingen har också gjorts under hela senare hälften av 1990-talet och publicerats i TemaNord-serien.

Fråge- och problemställningarna i dessa utredningar och rapporter har beaktats i den här rapporten och behandlas främst ur en politisk synvinkel genom en kort beskrivning av de problem som finns och de lösningsmodeller som kan komma i fråga.

Utredningen stöder sig även på uppgifter och bedömningar som har tagits fram genom intervjuer med sakkunniga och relevanta parter för sändning av grannlands-Tv i Norden.

För klarhetens skull bör påpekas att när det i utredningen används ordet sändarföretag, sändarbolag eller organisation avses alltid ett s.k. public service-företag som fungerar i allmänhetens tjänst. 


\section{Nuläget}

\subsection{Mottagningen av grannlands-Tv i Norden}

\section{Kort om metoderna}

Analogt överspill av markbundna sändningar kan tas emot av personer som bor vid gränstrakterna inom sändningarnas sebarhetsområde. Den s.k. överspillmottagningen gör det möjligt att titta på nordiska public service-kanaler i alla andra nordiska länder än Island. Eftersom det inte sker någon vidaresändning av programinnehållet finns det inget behov av några immaterialrättsliga tillstånd eller avtal för att göra denna mottagning möjlig. Detta betyder att utbudet kan ses av vem som helst som har en televisionsapparat. Befolkningen i de nordiska länderna har gärna utnyttjat denna möjlighet och tittandet har långa traditioner.

Ytterligare tillgång till grannlands-Tv får nordborna via direktsända satellitkanaler med hjälp av parabolantenn. Denna s.k. direkta satellitmottagning ordnas liksom överspillmottagningen utan några vidaresändningsavtal, och är i och för sig en enkel lösning. Den som önskar se kanalerna behöver endast skaffa sig nödvändig apparatur och ett åtkomstkort, eftersom kanalerna oftast är krypterade.

Mottagningen av grannlands-Tv har utvidgats genom vidaresändning av public service-kanaler via kabel. På detta sätt har det varit möjligt att se bl.a. Tv Finland i delar av Sverige och t.ex. SVT 1 och SVT2 i delar av Österbotten i Finland. I dessa fall måste den som vidaresänder programutbudet via kabel ha en vidaresändningslicens av rättsinnehavarna.

\section{Tillgängligheten av grannlandskanaler i Norden idag} I Danmark kan svT ses av 52,5 \% av alla danska hushåll, däri inkluderat de $16,2 \%$, som tar emot programutbudet via överspill. De 
norska kanalerna NRK 1 och TV2 ses av ca en tredjedel av de danska hushållen antingen via egen antenn, kabelnät eller centralantennsystem. En redigerad kanal av TV-program från Finland (sedan oktober 1997 »TV Finland«) kan tas emot via satelliten med en parabolantenn (DTH).

I sydvästra Finland, på Åland och i Österbotten kan svT: s marksändningar tas emot direkt eller via kabel-TV-näten. Den satellitsända SvT Europa kan ses i södra Finland i marknäten eller via kabel. DR 1 och DR2 hör till Canal Digitals programutbud och kan ses via individuell parabolantenn av finska kunder för 23 euro per månad. Sveriges Tv4 kan ses i norra Finland genom överspill och $i$ en del av kabelnäten. Även svт:s digitala Barnkanalen hör till det avgiftsbelagda kabelteveutbudet i Vasa.

Island befinner sig på randområdet för de nordiska satellitsändningarna. NRK 1 och TV Finland kan ses med parabolantenn. Det isländska telebolaget Siminn har på testbasis vidaresänt sex nordiska Tv-kanaler. Kanalerna sänds till isländska hushåll via satellit genom snabba bredbandsförbindelser. Sändningarna når en knapp tredjedel av alla isländska hushåll. Över $80 \%$ av de isländska hushållen har bredbandsförbindelser och antalet ökar hela tiden. För närvarande vidaresänds programutbudet enbart i kabelnätverket. Isländska TV-kanaler kan inte ses i andra länder.

SVT:s sändningar ses i många delar av Norge bl.a. genom överspill i Oslo-området. År 1993 var täckningen i Østlandet ca 44 \%, i Sørlandet ca $14 \%$, i Vestlandet ca $17 \%$, i Trøndelag ca $29 \%$ och i Nord-Norge ca $11 \%$. Men t.ex. i Finnmarken var täckningen endast 4,8\%. SVT 1 och svT 2 sänds av Telenor till satelliten och förvandlas till analog signal av kabeloperatörerna, som vidaresänder den i sina nätverk. DR 1 och DR 2 och TV Finland sprids i Norge per satellit.

I Sverige kan DR 1 och TV2/Danmark samt NRK1 ses direkt, via kabelnäten eller genom individuell parabolmottagning i olika slags baspaket eller större paket. Även DR2 kan ses genom överspill på ett litet område nära den danska gränsen. Dessutom kan man i västra Sverige samt i de norra gränsområdena se Norges NR K 1 och TV2 samt YLE TV1, YLE TV2 och MTV3 direkt eller via kabelnäten genom överspill. Tv Finland vidaresänds också i kabelnäten på 26 
orter i Sverige utanför marksändningarnas sebarhetsområde. TV Finland kan ses i marknätet på Storstockholmsområdet (se nästa stycke).

Nästan alla nordiska TV-kanaler som sänds via satellit, är krypterade (Conax m.m.). Mottagning av krypterade satellitkanaler förutsätter att signalen dekrypteras genom nödvändig utrustning (t.ex. åtkomstkort, smart card). Vidaresändning av krypterade satellitkanaler i kabel sker varierande så att den programbärande signalen först dekrypteras av kabeloperatören enligt avtal med sändaren och sänds sedan krypterad vidare i kabel eller så att programutbudet som sådant, dvs. krypterat sänds vidare direkt till mottagaren.

Den grova bild av tillgången till grannlands-Tv som ges i detta avsnitt visar att utbudet av grannlands-TV i vissa fall når väsentliga delar av de nordiska hushållen, medan det $i$ andra fall endast kan följas av en bråkdel av hushållen. Det finns sålunda ett brett utrymme för utvidgning av tillgång till grannlands-TV.

Mer detaljerad information om utbudet och tittarsiffrorna finns i Nordiska ministerrådets rapport "Grannlands-TV vid övergången till digitala sändningar« (Marina Österlund-Karinkanta, oktober 2001).

\section{Vidaresändning av grannlands-Tv i marknäten}

i Finland och Sverige samt på Åland

Mellan Sverige och Finland, i motsats till övriga Norden, har man tagit i bruk vidaresändning av marksändningar i marknäten.

Den redigerade satellitkanalen Tv Finland vidaresänds via Nackasändaren i marknätet över Storstockholm. Vidaresändningen sköts sedan början av 1990-talet av det Sverigefinska Riksförbundet (Ruotsinsuomalaisten keskusliitto).

Den motsvarande svenska satellitkanalen svT Europa vidaresänds över fyra sändare av YLE i södra Finland. Sändarna byggdes 1988-1989. Sändningarna når ca en tredjedel av de finska hushållen.

I Österbotten i Finland har man kunnat ta del av Sveriges television så att överspillet från svT 1:s och sVT2:s marksändningar tagits emot och sänts vidare i marknäten. Nuförtiden tas signa- 
lerna i stället ner från satelliten och sänds vidare av Bötombergets respektive Paradisbackens marksändare.

På Åland, som är enspråkigt svenskt, har utbudet av svenska sändningar varit nödvändigt. Idag sker ingen mottagning av överspill på Åland. Däremot återutsänder man på Åland tre marksända kanaler av vilka en är redigerad av YLE:s svenskspråkiga programutbud, dvs. huvudsakligen av FST:s sändningar. De två andra återutsända kanalerna är svT 1 och svT2. På Åland har vidaresändning i marknäten av de digitala kanalerna SVT 1, SVT2, Barnkanalen och SVT24 påbörjats i oktober 2003. I oktober 2004 kommer man även att kunna se Sveriges TV4, Finlands YLE TV1-D och YLE TV2-D samt YLE FST.

\section{2 Övrigt nordiskt radio- och televisionssamarbete}

Utöver möjligheten att se varandras public service-kanaler har man i Norden utövat vidsträckt samarbete inom bl.a. programproduktion och programutbyte. Det finns sedan gammalt flera välfungerande samarbetsformer på detta område mellan de nordiska public service-bolagen. Regeringarna eller Nordiska ministerrådet har i vissa fall fungerat som en katalysator för samarbetsarrangemangen.

Samarbetet på dessa områden kan även fördjupas under den redan pågående ändringen av TV-landskapet och särskilt när det handlar om förbättrad programverksamhet för språkliga och etniska minoriteter. De succéer som uppnåtts genom samarbetsarrangemangen hittills motiverar säkert public service-bolagens ledning och även regeringarna att utveckla, undersöka och förverkliga nya idéer för samarbete.

Dessutom finns det ett särskilt område där samarbete på ett nordiskt plan är ytterst viktigt, nämligen det tekniska samarbetet. Detta framhävs av att många nya möjligheter till utvidgad tillgång till grannlands-Tv är beroende av innovativ tillämpning av teknologi. 


\section{Nordvisionen}

Genom programutväxlingen mellan public service-bolagen blir en viktig del av vissa programkategorier tillgängliga för alla tittarkretsar i de nordiska länderna. I dessa fall blir programmen från grannländerna beståndsdelar i det nationella TV-utbudet och tillgången till utbudet i grannlands-Tv okomplicerad.

Nordvisionen är ett samarbetsarrangemang mellan nordiska public service-företag ( $D R$, NRK, RUV, SVT, UR Och YLE). Inom Nordvisionen har man samarbetat med programutväxling och samproduktioner av olika slag sedan 1959. En viktig del av programutväxlingen inom Nordvisionen har organiserats som s.k. gratisutväxling av i synnerhet faktaprogram. Gratisutväxlingen uppgick år 2002 till 1155 timmar. Årligen sänds totalt ca 2300 timmar program som har utbytts via Nordvisionen. Detta betyder att varje deltagande $\mathrm{TV}$-bolag varje dag året om sänder mera än 1 timme 15 minuter programmaterial som har förmedlats via Nordvisionen. Samproduktion har organiserats inom olika programgrupper varav de mest aktiva är Drama, Fakta och Barn och ungdom. Till samarbetet hör utöver substansmässigt samarbete även samarbete inom teknik och administration.

Även om programutväxlingen har nått en ansenlig volym, har den här typen av tillgång till grannlands-Tv sina begränsningar. En begränsande faktor är bolagens egen programpolitik. För att garantera en bredare tillgång till grannlands-Tv måste man arbeta för lösningar som baserar sig på vidaresändning av kanalernas innehåll antingen som sådana eller redigerade. Digitaliseringen av marknäten ökar sändningsutrymmet mycket och förbättrar därmed möjligheterna till ett utvidgat nordiskt programutbyte, vilket kulturpolitiskt är synnerligen viktigt.

\section{Nordiska TV-samarbetsfonden (kabelfonden)}

Kabelfonden grundades genom ett avtal mellan Nordvision-företagen 1987. Fondens verksamhet finansieras med de intäkter som inflyter av vidaresändningen av grannlandstevekanalerna i kabel. Via kabelfonden produceras huvudsakligen programutbud inom drama, barn och ungdom. Dessutom finansieras en del extra kost- 
nadskrävande faktaprogram via kabelfonden. Kabelfonden stöder dessutom olika projekt för forskning i och utveckling av nordiskt TV-samarbete. De medel som årligen fördelas av kabelfonden uppgår numera till 60 miljoner NOK. Fonden förvaltas av Nordvisionens sekretariat i Oslo. Ju mera man ökar sändningen av nordiska tv-program i grannländernas kabelnät, dess mera ökar fondens inkomster.

Nordiska film-och TV-fonden (NFTF)

Nordiska film- och TV-fonden (NFTF) grundades år 1989 på initiativ av Nordiska ministerrådet genom ett avtal mellan ministerrådet, de nordiska filminstituten och de nordiska public service-företagen. NFTF understöder produktionen av audiovisuella projekt $\mathrm{i}$ de nordiska länderna genom att delta i finansieringen av långfilmer, TV-drama, TV-serier, kortfilmer och kreativa dokumentärer. Särskild hänsyn tas till produktioner med barn och ungdomar som målgrupp. T.ex. år 2002 beviljade NFTF ca 65 milj. NOK i projektstöd. Stödet delas ut som produktionsstöd för fiktions- och dokumentärfilmer samt stöd för projektutveckling, distribution och versionering. Fonden har dessutom under de senaste åren förvaltat medel från Nordiska ministerrådet för filmkulturella åtgärder och stöd för fortbildning på filmområdet.

Det tekniska samarbetet - NorDig

Nordiska public service-bolag har sedan 1997 samlats i samarbetsgruppen NorDig. NorDig har behandlat frågor om standardisering av mottagningsutrustning, s.k. set-top-boxar för digital Tv, samt system för åtkomstkontroll (kortsystem) och programvara för interaktiva tjänster. Inom ramen för NorDig tog bolagen redan $\mathrm{i}$ mars 2001 ett beslut om övergång ("migration«) till ett öppet system för interaktivitet (DVB-MHP). Förseningarna i färdigställandet av specifikationerna samt $i$ industriernas implementering ledde till att NorDig i oktober 2002 fastställde en ny plan om migration. Planen var den första i sitt slag i Europa, och den är ett viktigt steg för utvecklingen av digital TV i Norden. 


\section{Medieutvecklingens ramvillkor och den audio- visuella politiken inom EU}

Den integrationsutveckling som pågår i EU - i synnerhet med tanke på de nya medlemsstaterna - utgör en mycket viktig referensram för det nordiska samarbetet och det nordiska agerandet. På många områden ordnas informationsutbyte mellan de nordiska länderna, och ståndpunkter och samfällda initiativ inom EU diskuteras.

EU:s utvidgning innebär att tio nya medlemsstater kommer med i unionen. Detta kommer antagligen att betyda att regionernas roll stärks. Det nordiska samarbetet kan då få en starkare regionalpolitisk roll än vad det nu har - om politikerna så vill.

I det följande refereras kort sådana EU-handlingar som är relevanta för denna utredning.

\section{EU-direktiv}

Inom EU har det givits direktiv om hur vissa av de frågor som rapporten gäller ses i ljuset av den europeiska inre marknaden. Europeiska unionens regler om den inre marknaden garanterar fri rörlighet för varor, tjänster, kapital och människor. Inom den inre marknaden skall även televisionstjänsterna kunna röra sig fritt oberoende av nationella gränser.

Direktivet »television utan gränser ( $89 / 552$ / EEG) gavs 1989 och reviderades 1997. Huvudprincipen i direktivet är att möjliggöra att televisionstjänster kan ses i alla medlemsländer trots nationell lagstiftning eller administration m.m. En revidering av direktivet planeras igen. 
Huvudprincipen i direktivet bygger på den s.k. sändarlandsprincipen: om programinnehållet är förenligt med sändarlandets lag får spridningen inte hindras i andra EEs-länder. Direktivet ställer vissa harmoniseringskrav på den nationella lagstiftningen även i Norden.

Ett annat direktiv som inverkar på vidaresändning av grannlands-TV är rådets direktiv om samordning av vissa bestämmelser om upphovsrätt och närstående rättigheter till satellitsändningar och vidaresändning via kabel (93/83/EEG), dvs. satellitdirektivet.

Direktivets syfte är att inom gemenskapen harmonisera de regler som gäller satellitsändningar och vidaresändning av rundradiosändningar via kabel samt vissa avtalsarrangemang som är kopplade till denna verksamhet.

I satellit- och kabeldirektivet framhävs att det inom den inre marknaden skall formas ett område utan interna gränser. En av de viktigaste orsakerna till direktivet var den osäkerhet som orsakades av skillnaderna i de nationella upphovsrättsliga bestämmelserna i medlemsstaterna.

Till den relevanta regleringen av TV-marknaden hör även det så kallade telecom-paketet, dvs. fem direktiv från år 2002 som reglerar villkoren för telekommunikationsmarknadens verksamhet på bred basis. Ett av dem är Europaparlamentets och rådets direktiv (2002/22/EG) om samhällsomfattande tjänster och användares rättigheter till elektroniska kommunikationsnät och kommunikationstjänster (Directive on universal services and users), som tillåter att medlemsstaterna introducerar must carry-förpliktelser för sådana nät som används för distribution av radio- och TV-sändningar. Ett villkor för detta är att kabelnätet är det huvudsakliga medlet för att ta del av radio- och TV-program för ett betydande antal användare. Förpliktelserna kan åläggas endast då de är nödvändiga för att fylla klart definierade mål om allmännyttighet. Förpliktelserna skall vara proportionella och transparenta.

Den audiovisuella politiken inom $\mathrm{EU}$

EU-kommissionen gav under sommaren 2000 ett meddelande om principer och riktlinjer för gemenskapens audiovisuella politik i den digitala eran (ком (1999) 657 - C5-0144/2000). Kommissionen 
betonade i meddelandet att det är medlemsstaternas sak att definiera nationella regler för innehåll och bestämma över sådana grundläggande frågor som t.ex. tidsplanen för upphörandet av de analoga marksändningarna. Kommissionen konstaterade vidare att europeiskt samarbete är viktigt, särskilt när det gäller spektrumplanläggning, bl.a. frekvenskoordinering och informationsutväxling.

Med anledning av meddelandet uppmanade Eu-parlamentet $\mathrm{i}$ sin resolution (A5-0209/2000) EU:s ministerråd och medlemsstaterna att komma överens om att vidta åtgärder för att så småningom bestämma om en gemensam övergång till digital TV, särskilt till markbunden digital Tv. Parlamentet hänvisar till betydelsen av en allmän och obehindrad spridning av Tv-utbudet $\mathrm{i}$ Europa. Rättsligt kan detta garanteras genom must carry-bestämmelser.

Kommissionens meddelande om övergången från analoga till digitala sändningar EU-kommissionen gav i september 2003 ett meddelande till rådet, europaparlamentet och europeiska ekonomiska och sociala kommittén om övergången från analoga till digitala sändningar (ком (2003) 541 slutlig). I meddelandet framhävde kommissionen att trots att beslutet om övergång till digitala sändningar skall fattas av varje medlemsstat för sig bör övergången ske i enlighet med gemenskapslagstiftningen, särskilt de nämnda fem telecom-direktiven.

Enligt meddelandet förutsätter det s.k. switch off-beslutet en noggrann övervägning och beredning, eftersom övergången inte enbart handlar om en övergång av teknisk natur, utan även om en positiv utveckling som avser att ge konsumenten ett kvantitativt och kvalitativt mervärde genom ökat utbud och högre kvalitet på tjänster, främst tack vare den digitala komprimeringen. Att försöka tvinga fram en övergång mot industrins och användarnas vilja kan leda till ohållbara följder. Inom Eu planeras därför inte något förslag om ett gemensamt datum om att lägga ned de analoga 
sändningarna eller t.ex. något förbud mot försäljning av analoga TV-mottagare på EU-nivå.

I meddelandet anses att det bästa och mest hållbara sättet att sköta digitaliseringen är att medlemsstaternas myndigheter främjar en marknads- och konsumentledd strategi. För att inte helt lämna saken på industrins axlar borde alla medlemsstater bestämma sig för en politisk insyn och bl.a. se till att allt sker utan snedvridning av marknaderna eller ställningen mellan olika operatörer. Proportionalitet och teknikneutralitet bör känneteckna de allmänna politiska åtgärderna på nationell nivå.

Kommissionen uttryckte i meddelandet sin vilja att delta i övergångsprocessen bl.a. genom åtgärder på området för apparatstandardisering, statusanalysering inom EU och tillräcklig konsumentinformation.

Övergången till digital Tv bör vara en allomfattande process som inbegriper olika nät, affärsmodeller och tjänster, inklusive gratiskanaler (dvs. okodade sändningar - s.k. free-to-air, FTA), bättre bildkvalitet samt informationstjänster och interaktiva tjänster. De nationella marknaderna för digitala sändningar, och den politik som förs, kommer att bevakas även i fortsättningen.

För närvarande är kommissionens meddelande under behandling i ministerrådet och parlamentet.

EU har i handlingsplanen eEurope 2005 uppmanat alla medlemsstater att senast i december 2003 offentliggöra sina avsikter med övergången. Nedan beskrivs de åtgärder som i Norden gjorts med avseende på digital $\mathrm{Tv}$ och public service. 


\section{Utvecklingen av digital TV och public service}

\subsection{Tekniska framsteg inom televisionsverksamheten}

Digitaliseringen av distributionssätten och även själva innehållsproduktionen har lett till en enorm utveckling av radio- och televisionsverksamheten. Överallt finns det stora förväntningar på kvaliteten av programutbudet och dess mångsidighet, liksom på de tilläggstjänster som digital TV möjliggör. I alla de länder där digitala sändningar har introducerats, kommer man inom en överskådlig tid fatta beslut om övergång till enbart digitala sändningar. I detta avsnitt behandlas det tekniska läget för den nordiska televisionsverksamheten just nu och de planer länderna har i fråga om övergången till enbart digitala televisionssändningar.

Största skillnaden mellan analoga och digitala sändningar är att sändningarna i de digitala kanalerna sänds till mottagaren i s.k. kanalknippen (multiplex, MUX) bestående enbart av ettor och nollor.

Den första stora tekniska frågan angående digital Tv var valet av digitala sändningsstandarder. Som sändningsstandard valdes den europeiska ETSI-standarden DVB (Digital Video Broadcasting) som är en allmän standard för digital Tv. För att de digitala sändningarna kan ses behövs en mottagningsapparat, en s.k. digitalbox eller en digital television, där boxen är inbyggd. Digitalboxarna som finns till salu skall alltså vara förenliga med denna standard.

DVB-standarden delas i tre undergrupper: DVB-T för markbundna sändningar, DVB-C för kabelsändningar och DVB-s för satellitsändningar. Tekniskt sett är de olika undergrupperna lika men 
p.g.a. moduleringen av sändningen varierar de olika sändningssätten emellan, vilket betyder att mottagare som är avsedda för ett nätverk inte fungerar i ett annat. Trots att det tekniskt är möjligt att bygga en anordning som kan ta emot sändningar (twintuner) på flera olika sätt har tillverkarna i Norden inte hittills varit intresserade av att utveckla en sådan apparat. Detta betyder att för närvarande förutsätter alla olika sändningssätt en egen digitalbox. Marknaden för digitalboxarna, som egentligen kan ses som datamaskiner, är liten inte minst på grund av de nordiska språkens specialegenskaper.

NorDig gav i oktober 2002 ut en övergångsplan för en samnordisk API (Application Programming Interface; kompatibilitetsgränssnitt). DVB-MHP (Multimedia Home Platform) har fastställts som samnordisk gränssnittsstandard. MHP är en öppen standard som möjliggör interoperabilitet mellan operatorn och kundens mottagningsutrustning. Standardenlig mottagningsutrustning kan ta del av sådana interaktiva tjänster som sändningsbolagen erbjuder t.ex. vid sidan av själva programminnehållet i form av t.ex. elektroniska programguidar (EPG), banktjänster, supertext-TV m.m. Plats för åtkomstkort (med dekrypteringsuppgifter, bl.a. Conax) behövs ifall man avser att använda de tjänster som är avgiftsbelagda på ett eller annat sätt.

Finland tog i bruk DVB-MHP som första i världen. Standardenliga interaktiva tjänster kan tillsvidare endast utnyttjas i det markbundna nätet eftersom satellit- och kabeloperatörerna åtminstone i Finland inte tillsvidare använder sig av MHP-standarden.

Betydelsen av den sändningsstandard som Norden valt ökade avsevärt $\mathrm{i}$ internationellt hänseende när även Tyskland valde samma standard för sin digital TV. Övriga länder som beslutat sig för att i framtiden tillämpa DVB-MHP är USA, Korea, Singapore och Spanien. De facto är standarden inte i bruk på många andra ställen än i Finland men i framtiden kommer MHP i varje fall att vara den överlägset mest allmänna standarden för digitala TV-tjänster.

Avgörande för införandet och utvidgningen av digital $\mathrm{TV}$ är antalet digitalboxar eller digitala TV-apparater som hushållen anskaffar. För dem är det naturligtvis också avgörande hur intressant och lockande utbudet på de digitala kanalerna anses och vilken typ av 
mervärde allmänheten får tillgång till genom digital TV. Bakom det ökande intresset för digital Tv har hittills delvis varit de kommersiella aktörerna som stött hemelektronikmarknaden genom att via uthyrning eller andra sätt överlåtit digitalboxar till kunderna.

Trots att antalet hushåll som har digital mottagningsutrustning av något slag har stigit långsamt har man beräknat att vid årsskiftet 2003-2004 uppgår antalet digitala mottagare för markbunden mottagning till 200000 i både Finland och Sverige, vilket betyder knappa $10 \%$ och dryga $5 \%$ av alla hushåll i respektive Finland och Sverige. Av dessa är dock endast en bråkdel sådana som motsvarar MHP-standarden, dvs. sådana som kan förmedla interaktiva tjänster. Migrering till MHP-standarden vid tjänster i samband med satellit- och kabelsändningarna kommer sannolikt att bero på hur många MHP-digitalboxar för satellit- respektive kabelmottagning som finns till salu. Redan nästa år kan det förutses att dessas interaktiva tjänster utvecklas mot standarden MHP.

Den andra viktiga faktorn för utvecklingen av digital TV är förstås själva uppbyggandet av de digitala sändarnäten. Utbyggnaden av de fyra första multiplexerna täckte hösten 2003 hela $90 \%$ och den femte $50 \%$ av befolkningen i Sverige. I Finland var täckningen av sändarsystemet hösten 2003 drygt $70 \%$ av befolkningen och man har beräknat att näten sommaren 2004 nås av $95 \%$ av befolkningen. Att uppnå en täckning på $100 \%$ i alla nordiska länder är dock en ekonomisk utmaning.

Markbundna digitala nät kan på vissa områden kompletteras med satellitlösningar. Områden som ligger på gränsen av täckningsområdet för de markbundna nätverken kan täckas med satellitsändningar. Detta är åtminstone, vad gäller situationen i Norge, en relevant möjlighet att uppnå hög täckning för nationell digital TV. I Norge inverkar de geografiska förhållandena på både utbyggnadstakten och de tekniska lösningarna.

I jämförelse har Danmark de så att säga förmånligaste möjligheterna att bygga ut ett digitalnät som täcker alla hushåll i landet. Nätet väntas där vara till stora delar färdigbyggt under år 2005 .

Övergången till digitala sändningar med användning av DVBMHP medför inga nya hinder för tillgången till grannlands-TV och det finns goda förutsättningar för att utöka tillgången ytterligare. 
Tidpunkten för övergången till digitala sändningar är en stor politisk fråga i de nordiska länderna. I vissa länder har parlamentet eller regeringen fastställt datum för övergången, men funderar nu på att skjuta upp den.

I Sverige har de digitala sändningarna börjat redan i april 1999. Sveriges public service-kanaler är bl.a. svT1, svT2, Barnkanalen och svT24. Dessutom har TV4 en public serviceliknande ställning i Sverige. Regeringen överlämnade sin proposition om digital TV till riksdagen i mars 2003. Sedermera har det fattats beslut om att de analoga sändningarna skall läggas ned 1.2.2008. Närmare förutsättningar för uppbyggnaden av näten samt tillgängligheten och tillståndsgivningen ges i form av en regeringsproposition till riksdagen under vintern 2004.

I Finland har man sedan augusti 2001 sänt bl.a. följande kanaler i det digitala marknätet: YLE TV1-D, YLE TV2-D, YLE FST, YLE24, YLE Teema. Dessutom sänder TV Finland digitalt via satellit. Enligt regeringens principbeslut siktar Finland på att gå över till digitala sändningar år 2006. Detta beslut torde dock vara för optimistiskt. Ett förslag om övergången gavs av en parlamentarisk kommitté i början av december 2003. I kommitténs mellanrapport föreslogs att de analoga sändningarna skulle läggas ned 31.8.2007. Kommittén har följaktligen föreslagit att statsrådet skall fatta ett principbeslut i saken under föråret 2004.

I Norge har inget datum fastställts för övergång till digitala sändningar, men runt årsskiftet 2003-2004 skall Stortinget behandla frågan om utbyggnaden av ett digitalt markbundet nät i Norge. En ansökan om rätten att bygga ett dylikt nät är anhängigt och organisationen själv har förutspått att de analoga sändningara kommer att upphöra i slutet av 2007. De norska public service-kanalerna sänds digitalt via satellit, vilket medför att det nödvändigtvis inte kommer att utvecklas något heltäckande digitalt marknät i Norge.

I Danmark har man bestämt att man i första hand kommer att sända DR1 Och DR2 samt TV2:s public service-utbud både i analog och i digital form. Det förutsätter att det danska digitala nätet har byggts ut och tagits i bruk senast i juli 2005. Kulturministern kan besluta om att förlänga denna frist. Tillvägagångssättet baserar sig 
på ett tilläggsavtal till medieavtalet från september 2003. Sändningarna kommer att ske okrypterade. Public service-kanalerna skall enligt avtalet samarbeta med att bygga upp ett digitalt sändarnät och förvalta sändningskapaciteten tillsammans. Dessutom skall kanalerna utveckla digitala tjänster såsom text-Tv och tolkning på teckenspråk m.m. i sitt utbud.

På Island har en arbetsgrupp i början av 2003 gett sina förslag till hur digital Tv skall införas på Island. Arbetsgruppens primära resultat var att det på myndigheternas initiativ skall upprättas en gemensam plan för utsändningsverksamheten, eftersom alla på Island bör ha lika möjlighet att ta del av televisionsutbud. På Island har man inte fattat något beslut om övergång till digitala marksändningar även om det i utredningen framhölls att distribueringssättet för isländsk television behöver ändras och att digital TV skall fungera som en av drivkrafterna i informationssamhället. RUv har börjat med parallella digitala sändningar i det digitala marknätet $\mathrm{i}$ samarbete med Islands universitet. Dessutom har RUv även på försöksbasis sänt sitt programutbud via satellit men fortsättningen för denna verksamhet är beroende av att finansieringen ordnas.

Övergångsplanerna varierar från land till land men i varje fall är det frågan om en övergång som sker i hela Norden under detta årtionde.

I samband med övergångsprocessen bör det även beslutas om public service-verksamhetens framtid överlag och beslutens inverkan på tillgången till grannlands-Tv i de övriga nordiska länderna. Dessutom skall en rad andra viktiga frågor lösas, såsom t.ex. frågan om de ekonomiska konsekvenser av att man tittar på grannlands-Tv . Hittills har man antingen kunnat ta del av grannlands-Tv helt gratis eller mot ersättning av något slag. Efterfrågan på grannlands-TV varierar säkerligen beroende på de kostnader som är förknippade med de tekniska lösningarna och ifall mottagningen ordnas genom vidaresändning, av upphovsrättigheterna.

I alla nordiska länder är det en relevant fråga hur intresset för digitalboxar kan ökas. Möjligheten att anskaffa digitala mottagningsutrustningar till mycket billiga priser eller helt gratis har då och då kommit fram i diskussionen kring digital Tv. I Finland har 
frågan behandlats i den tidigare nämnda parlamentariska kommittés betänkande, där det konstateras att priset på digitalboxarna redan nu börjar vara på en rimlig nivå och att inga statliga stödåtgärder behövs utan saken löses bäst av marknaden.

Intresset för digital $\mathrm{Tv}$ har säkerligen ökat det senaste året till följd av att flera kommersiella satellitteveoperatörer har erbjudit digitalboxar som morötter vid abonnemangsavtal.

Det är även en öppen fråga hur man kunde organisera tillgången till de nordiska public service-kanalerna som sänds via satellit, så att alla i Norden t.ex. i form av högre licensavgifter eller lättare tillgång till åtkomstkort kunde ha möjlighet att se dem. Detta är naturligtvis en fråga som de nordiska public service-bolagen bör försöka lösa.

\subsection{Reglering och finansiering av public service-företag i Norden}

\section{Allmänt om reglering}

DANMARK. Lagen om radio- och televisionsverksamhet (Bekendtgørelse av lov om radio- og fjernsynsvirksomhet LBK nr 551 af 20/6/2000) är gemensam för alla som sänder radio eller television till allmänheten i Danmark och innehåller bl.a. särregler för Danmarks Radios verksamhet och förpliktelser och finansiering (radiooch TV-licens) samt bestämmelser om ledningen av DR. Denna reglering har tidigare kompletterats av en rad kungörelser om bl.a. stadgarna för DR och dess public service-uppgifter. År 2003 ingicks två separata kontrakt om public service-uppgifterna mellan kulturministern och respektive DR och TV2. Kontrakten preciserar förpliktelserna när det gäller bl.a. tjänster till döva och andra handikappade samt dansk konst, kultur, språk och film.

FINLAND. Det statsägda radio- och televisionsbolagets allmännyttiga verksamhet (s.k. public service-verksamheten) regleras förutom i lagen om Rundradion Ab (1380/1993) också i lagen om televisions- och radioverksamhet (744/1998). Enligt den skall YLE 
tillhandahålla ett heltäckande televisions- och radioprogramutbud jämte special- och tilläggstjänster för alla på lika villkor. Närmare beskrivning av uppgifterna finns i bestämmelsens $7 \S 2 \mathrm{mom}$. Reglerna om skyldighet att distribuera vissa televisions- och radiosändningar (must carry-reglerna) för kabeloperatörer finns i 134 § i kommunikationsmarknadslagen (393/2003). Ytterligare regleras YLE:s verksamhet av lagen om televisions- och radiofonden (745/ 1998) vars syfte är att ordna finansieringen av YLE:s verksamhet. Lagen reglerar fastställande och uppbärande av TV-licensavgifter och koncessionsavgifter, vilka utgör grunden för YLE:s finansiering. De förstnämnda betalas till televisions- och radiofonden av ägare till TV-apparater och de senare av koncessionsinnehavare, varifrån den kanaliseras till YLE. Den 25 juli 2003 (396/2003) har lagen om Rundradion $\mathrm{Ab}$ ändrats så att YLE skall lämna en rapport om sin public service-verksamhet till Kommunikationsverket. På detta sätt förbättras kontrollen av hur public service-uppgiften har verkställts i enlighet med bestämmelserna.

ISLAND. Public service-företaget (RUv) regleras på Island dels genom radiolagen (Radioloven, 53/2000), och dels genom lagen om Islands Radio (Lov om Rikisutvarpid, 122/2000). I den förra finns bl.a. bestämmelser om rätten att sända radio och TV, tillstånd att driva radio- och TV-verksamhet, radio- och TV-stationers förpliktelser. Lagen om Islands Radio redogör för RUv:s public service-förpliktelser 11 § i radioloven. Radiorådets uppgift är att övervaka att RUv:s public service-uppgifter uppfylls.

NORGE. Lagen och förordningen om rundradiering (Lov om kringkasting (1992-12-04-nr 127) och Forskrift om kringkasting 1997-02-28 nr 153) är gemensamma för alla som sänder radio och television till allmänheten i Norge. Lagen innehåller generella bestämmelser om koncession, vidaresändning $\mathrm{i}$ kabelnät, TV-innehav och TV-avgift samt ett särskilt kapitel om Norsk Rikskringkasting AS:s (NRK) verksamhet. Kulturministern har kompletterat dessa bestämmelser med stadgar och ytterligare bestämmelser om NRK:s verksamhet. Enligt dessa behöver NRK bl.a. ingen koncession för sina sändningar som public service-företag, vars uppgifter även har räknats upp i lagen. 
SVERIGE. Radio- och TV-lagen (1996:844) är gemensam för alla som sänder radio eller Tv till allmänheten i Sverige. Lagen innehåller förutom samtliga allmänna regler om radio- och televisionsverksamheten även bestämmelser om vidaresändning i kabelnät samt ett särskilt kapitel om närradio och lokalradio. Sveriges public service-verksamhet är som en nordisk kuriositet uppdelad på tre olika företag, Sveriges television (SVT), Sveriges Radio (SR) och Utbildningsradion (UR). Dessa företag som public service-företag regleras dels genom radio- och TV-lagen, dels genom respektive företags sändningstillstånd och anslagsvillkor. Sändningstillståndet, som beviljas av regeringen, gäller för viss tid och kan kombineras med ett antal villkor, bl.a. om utformning, innehåll och distribution av sändningarna samt villkoren för reklam och sponsring. Av sändningstillståndet framgår bl.a. respektive företags public serviceuppgifter, som är underställda en särskild granskningsnämnd. Sveriges public service-kanaler finansieras genom en TV-avgift i enlighet med lagen om TV-avgift (1989:41).

Radio- och TV-verksamheten inom de självstyrande områdena Åland, Grönland och Färöarna har i respektive land reglerats på motsvarande sätt. På ÅLAND regleras radio- och televisionsverksamheten i landskapslagen om rundradioverksamhet ( $\AA$ FS 117/93), i landskapslagen om kabelsändningsverksamhet till allmänheten (ÅF 53/93) och landskapsförordningen om rundradio- och kabelsändningsverksamhet till allmänheten. I lagarna finns bestämmelser om bl.a. tillstånd att driva radio- eller tele-visionsverksamhet. Ålands radios public service-förpliktelser har tagits in i dess bolagsordning. Public service-verksamheten finansieras huvudsakligen med licensintäkter. För olika ändamål, bl.a. för finansiering av en ny sändare, har små bidrag betalats av landskapsstyrelsen till Ålands Radio under de föregående åren. Ett sådant bidrag ingår dock inte i nästa års budget.

På GRÖNLAND regleras radio- och TV-verksamheten i landstingsforordningen (radio- og TV-forordningen) som bl.a. innehåller regler för public service-bolaget KNR och av vilken innehållet i public service-förpliktelsen framgår. 
På FäRÖARNA finns bestämmelserna om radio- och televisionsverksamhet i lagen om radio och TV (1l Nr. 22/1998), som innehåller bestämmelser bl.a. om företagens rätt att sända ut radio och TV på Färöarna, och särskilda kapitel om Færøarnas Radio (ÚF, Færøarnas TV (SvF)). Verksamheten finansieras med licensmedel och reklamintäkter i en viss proportion.

Nödvändiga ändringar för att nå överensstämmelse med TVdirektivet har gjorts i samtliga nordiska länder.

\section{Must carry-reglernas omfattning}

Det finns regler om förmedlingsförpliktelsen i alla nordiska länder. Kabeloperatörerna skall vidaresända vissa kanaler i sina nät. För nuvarande är omfattningen av must carry-principen, när det gäller Tv, följande:

DANMARK. Enligt $6 \S$ i Lov om radio och fjernsynsvirksomhed bör public service- innehållet av DR 1 och TV2/ Danmark samt dessas regionala sändningar sändas i kabelnäten. Digitala program skall förmedlas endast om kabelanläggningen sänder annat digitalt utbud.

FINLAND. Enligt 134 i i kommunikationsmarknadslagen omfattas de kanaler som sköter om den allmännyttiga verksamheten av kabeloperatörernas förmedlingsplikt (i praktiken YLE TV1, YLE TV2, MTV3 och Fyran). Kabeloperatören behöver inte p.g.a. denna plikt göra förbättringar i nätets distributionsförmåga för att uppfylla denna förpliktelse, dvs. sänder bolaget annars digitalt inkluderas även de digitala public service-kanalerna i förmedlingsplikten.

NORGE. Enligt 4 kap. i lov och forskift om kringkasting skall NRK:s sändningar, TV2:s sändningar och lokala sändningar som sker med koncession vidaresändas i kabelnätet.

SVERIGE. Enligt 8 kap. i radio- och TV-lagen finns en skyldighet att vidaresända program i vissa fall. I de analoga kabelnäten måste public service-kanalerna svT1, svT2 samt TV4 vidaresändas. Om kabelnäten har digitaliserats är operatören skyldig att vidaresända även den digitala kanalen SVT 24. Radio- och TV-lagsutredningen 
har nyligen lagt fram ett förslag till revidering av bestämmelserna om must carry genom delbetänkandet Must carry (sou 2003:109).

På ISLAND finns inga lagbestämmelser om must carry. Trots detta förmedlar Siminn, som är den isländska kabelanläggningen, i praktiken det isländska public service-bolagets RUv:s utbud i sina nätverk.

I princip är det möjligt att tillämpningen av en sådan must carryprincip kan utsträckas till kanaler från andra nordiska länder. En sådan princip kunde under vissa förutsättningar gälla de nordiska redigerade satellitkanalerna. Den avgörande faktorn kan vara t.ex. kabelnätets vidaresändningskapacitet eller dess fria kapacitet.

Kort om finansiering

Alla nordiska public service-företag finansieras alltså huvudsakligen med intäkter från Tv-licensavgifter; i Danmark och Island tas motsvarande avgift ut även för radioapparater. I Finland utgörs en del av YLE:s finansiering av koncessionsavgifter som betalas av kommersiella programföretag. Alla nordiska länder reglerar fastställandet och indrivningen av licensavgiften i särskilda lagar. Möjligheterna för annan finansiering av public service-verksamhet i de nordiska länderna, förutom RUv, är dåliga på grund av förbuden mot reklamsändningar. I vart fall är avsikten med förbudet att motarbeta förvanskningen av hela syftet med public service-verksamheten och finansieringen av public service-företagen. På Island är dock finansiering av RUV möjlig genom reklamintäkter på vissa villkor. För s.k. sponsrade sändningar finns det varierande lösningar i samtliga nordiska länder.

En viktig fråga är hur finansieringen av public service skall ordnas i framtiden, när apparaterna konvergeras så att de inte bara är avsedda för televisionsmottagning, vilket nu i allmänhet är grunden för avgiften. Detta är emellertid inget problem för Finland eftersom bestämmelsen redan nu på ett effektivt sätt täcker även sådana hybridanordningar. 


\subsection{Marknaden, public service-verksamhetens framtid, konkurrensfrågorna}

Detta avsnitt behandlar frågor kring bevarande och främjande av den nordiska public service-verksamheten i en framtid med ökande internationalisering, kommersialisering och teknisk utveckling.

Utanför Norden har utvecklingen av den digitala marknaden och konkurrensen där hittills varit mycket beroende av de kommersiella operatörerna. I hopp om utvidgat intresse har operatörerna även i Norden börjat erbjuda digitalboxar till kunderna för en begränsad tid utan kostnad. Detta har varit möjligt eftersom de fungerar på kommersiella grunder. Intresset för digitalboxar för mottagning av markbundna sändningar har varit lågt fram till nu, åtminstone i Finland och Sverige.

För att kunna skapa en sund konkurrens inom digital distribution även på den framtida multimediemarknaden är det viktigt att även public service-företagen i högre grad kommer in på denna marknad. Public service-bolagen bör ha möjligheter att utveckla sin programverksamhet enligt samma digitala villkor som de kommersiella företagen, eftersom public service-företagens utbud är något som kulturpolitiskt sett inverkar på var och en i hela Norden.

Finansieringen av public service-kanalerna har hittills skötts huvudsakligen via TV-licensavgifter (i Finland även koncessionsavgifter). Avgifterna avser att täcka kostnaderna för de public service-uppgifter som företagen enligt lagen har. Det beror mycket på finansieringen vilka möjligheter public service-företagen har att konkurrera på den framtida mediemarknaden.

Public service-bolagen har utvidgat sina aktiviteter till nya verksamhetsområden; detta förutsätter att bolaget kontrollerar vilket förhållandet mellan de lagstadgade public service-förpliktelserna och den övriga verksamheten är. När verksamheten utvidgas måste bolaget överväga om nya intäktskällor behövs och i vilken utsträckning de i så fall är möjliga.

Eftersom public service-verksamheten i största delen av Europa är bestämd i lag och övervakad i olika grad samt finansierad med 
licensintäkter har det uppstått problem i fråga om konkurrensreglerna på radio- och televisionsmarknaden. Ett särskilt problem har i detta sammanhang ansetts vara det att vissa public service-företag finansierar sin verksamhet med reklaminkomster (»blandad finansiering (). I EU har ett antal klagomål riktats till kommissionen om statsstöd i samband med public service-verksamheten. Klagomålen beror närmast på att den licensbaserade finansieringen har ansetts som ett statsstöd. Dessutom finansieras en del public service-verksamhet i en del länder direkt via statsbudgeten.

Ett politiskt delresultat av debatten om public service-verksamhetens ställning är det TV-protokoll som 1997 togs in i Amsterdamavtalet. Enligt protokollet skall systemet för radio och TV i allmänhetens tjänst i medlemsstaterna ha ett direkt samband med de demokratiska, sociala och kulturella behoven i varje samhälle och med behovet att bevara mångfalden i medierna.

Enligt protokollet skall bestämmelserna i Europeiska gemenskapernas fördrag inte påverka medlemsstaternas behörighet att svara för finansiering av radio och TV i allmänhetens tjänst. Detta gäller alla de fall denna finansiering beviljas till radio- och TV-organisationerna för att utföra det uppdrag att verka $i$ allmänhetens tjänst som tilldelats dem av medlemsstaten. Sådan finansiering får inte påverka handelsvillkoren och konkurrensen inom gemenskapen i en sådan utsträckning att det skulle strida mot det gemensamma intresset, varvid kraven på att utföra uppdraget att verka i allmänhetens tjänst skall beaktas.

I januari 1999 godkände rådet en resolution om radio och TV i allmänhetens tjänst. Resolutionen repeterade innehållet i protokollet och betonade dessutom utvecklandet och diversifieringen av rundradioverksamheten i den digitala eran och dess uppgifter $i$ att erbjuda pluralt programutbud till omfattande publiker.

För garanterande av rättssäkerheten av finansieringen av public service-bolagen gav kommissionens generaldirektorat för konkurrensärenden år 2001 ett meddelande (Europeiska gemenskapernas officiella tidning 2001 / C 320/5) om tillämpningen av statsstödsreglerna på offentliga finansieringen av public service-verksamheten. Enligt meddelandet är offentlig finansiering av verksamheten möj- 
lig ifall den nytta som fås från verksamheten är större än de inskränkningar verksamheten medför i konkurrensen (proportionalitetstestet).

I dagarna har kommissionen fattat två beslut med anledning av några av klagomålen som riktats till kommissionen om det offentliga stödet. Bl.a. i beslutet gällande Frankrike (IP / 03/1666, 10.12.2003), som var förenligt med det tidigare beslutet gällande Italien och Portugal och meddelandet från år 2001, konstaterade kommissionen att offentligt stöd är förenligt med gemenskapens konkurrensbestämmelser om stödet som beviljats public servicebolaget inte överstiger de kostnader som förverkligandet av en $\mathrm{i}$ lag baserad public service-förpliktelse medför. Kommissionen framhöll överlag att finansieringen av public service-verksamheten skall vara transparent och innehålla garantier som motarbetar överdimensionerat stöd. 


\section{Grundprinciperna för de upphovsrättsliga lösningarna}

\subsection{Allmänt}

Upphovsrätten, rätten till programinnehållet och signalen, är faktorer som måste tas hänsyn till när vidaresändning och mottagning av grannlands-TV organiseras. Upphovsrätten är den ekonomiska grunden för spridning av kultur och information. Trots att förhandlingarna om rättigheterna kan vara svåra måste parterna inse att upphovsrätten som sådan inte i detta sammanhang får betecknas som ett problem.

Utgångspunkten är för närvarande att TV-bolagen skaffar sändningsrättigheter till programinnehållet territoriellt, dvs. för det egna opereringsområdet (landet, regionen). Den som vill organisera tillgängliggörande av sändningar utanför detta territorium skall klarera rättigheter till det utvidgade mottagningsområdet.

Mottagningsområdet för satellitsändningar utgörs oftast av flera länder. Sändningarna kan vara mottagbara för enskilda hushåll eller så levereras de till hushållen i kabelnät. Vidaresändningen i kabelnäten är upphovsrättsligt en ny relevant sändningsfas för vilken rättigheter måste klareras. Skyldigheten gäller både utanför sändningens mottagningsområde (som kräver transport av signal till vidaresändningsplatsen) och på områden där sändningen kan ses direkt.

En utmaning för rättighetsklareringen är det faktum att en televisionssändning och dess innehåll är föremål för rättigheter hos ett stort antal rättighetshavare. Dessutom varierar rättigheternas karaktär från grupp till grupp. En televisionskanal har följande rättighetshavare: 
- Upphovsmännen har på grund av sin ensamrätt en uteslutande rätt att bestämma över bruket av deras verk inklusive vidaresändning av sändningar som innehåller deras verk. Till de relevanta rättighetshavarna för upphovsmännens del hör kompositörerna, regissörerna, manuskriptförfattarna och scenkonstnärerna.

- Utövande konstnärer och fonogramproducenter har i Norden vanligtvis en rätt till ersättning för vidaresändningen.

- Filmproducenternas ställning i förhållande till vidaresändningen baserar sig på de rättigheter som de får genom avtal med upphovsmännen i samband med produktionen.

- Radio- och TV-bolagen innehar två typer av rättigheter. Sändarbolagen har rätt att bestämma över bruket av sändningen, dvs. signalen inklusive vidaresändning för det första över luften eller via kabel. För det andra producerar sändarbolagen egna program och i samband med produktionen får de genom avtal rättigheter av upphovsmännen.

Långfilmsproducenterna innehar vanligtvis på basis av avtal med upphovsmännen alla rättigheter för filmen på marknaden, inklusive televisionen; i detta utgör ett undantag rättigheterna för offentligt framförande av musikaliska verk. Producenternas vidaresändningslicens baserar sig sålunda på upphovsrätten hos de utövande konstnärer som har bidragit till filmen. När det gäller annat audiovisuellt innehåll än långfilmer, producerat av utomstående producenter, varierar licensieringsbehovet beroende på ländernas avtalspraxis.

Licensieringsförfarandet och vem som är part i rättighetsklareringen kan variera från land till land även inom Norden, beroende på hur rättighetsförvaltningen är organiserad. Upphovsmännen, utövande konstnärer och fonogramproducenter har i alla nordiska länder bildat kollektiva förvaltningsorganisationer som har fullmakt att på rättighetshavarnas vägnar förvalta rätten till vidaresändning eller rätten till ersättning för vidaresändningen.

Även filmproducenterna i Norden har, utanför dessa organisationer eller inom ramen för dem, organiserat förvaltningen av sina 
ekonomiska intressen i samband med vidaresändningen av filmer på olika sätt.

De nordiska kanalerna innehåller också utländska filmer och annat program. De utomnordiska/internationella parternas ställning har i vissa fall en viktig inverkan på hur lösningar i fråga om spridningen av grannlands-Tv fungerar. Detta gäller bl.a. utomnordiska filmproducenter. I deras intresse kan ligga att vidaresändning organiseras i så begränsad omfattning som möjligt. En begränsad vidaresändning möjliggör en orubbad marknadsföring av deras produktioner från land till land.

När det gäller att utvidga möjligheterna att ta emot hela kanaler i andra länder eller områden uppstår frågan hur vidarespridningen kan organiseras på ett lagligt sätt. Problemet är och har varit den stora mängden rättsinnehavare, särskilt upphovsmän. En avgörande fråga är hur man kan uppnå heltäckande verkan i fråga om avtalslösningarna.

\subsection{Nuvarande lösning i Norden}

I de nordiska länderna har intresset för grannlands-TV alltid varit stort och i och med utvecklingen av tekniska vidarespridningsmöjligheter utreddes och löstes också upphovsrättsfrågorna tämligen tidigt. Den nordiska utredningsrapporten »Nabolands-TV i kabel« (1984) hör till det nordiska lagstiftningssamarbetets stora framgångar.

Historiskt sett lades samtidigt grundvalen för harmonierande lösningar i lagstiftningen i de nordiska länderna (1986-1987). Lösningsmodellen baserar sig på avtal som sedan kompletterats med bestämmelser i lag. Genom särskilda bestämmelser gavs avtalen en utvidgad verkan. Denna typ av rättighetsförvaltning kallas i upphovsrätten för avtalslicens.

Huvudsyftet med denna lösning var att garantera heltäckande arrangemang för de otaliga inhemska och utländska upphovsmän vars verk ingår i programutbudet. Denna typ av lösning behövs 
inte för sändarföretagens del: det finns bara få sändarföretag och dessa kan lätt kontaktas.

Avtalen om vidaresändning ingås mellan organisationer som företräder ett flertal inhemska upphovsmän (kriteriet har numera ändrats i vissa länder p.g.a. EU-synpunkter) och den part som vill vidaresända. Avtalen är direkt bindande och täcker de upphovsmän som organisationen företräder. Avtalslicensbestämmelsen ger vidaresändaren rätt att sända även verk av sådana upphovsmän som organisationen inte företräder. Denna verkan kan jämföras med den allmänt bindande verkan som kollektivavtalen i arbetsrätten har.

Avtalen förhandlas fram och ingås i de länder där vidaresändningen och mottagningen äger rum. Enligt denna s.k. mottagarlandsprincip sker klareringen av rättigheterna i det land där programutbudet vidaresänds $-i$ enlighet med landets lagstiftning.

Rättigheterna klareras med den upphovsrättsorganisation som representerar upphovsmännen i det land där vidaresändningen sker. Upphovsrättsersättningen betalas av den som sänder vidare. Denna modell fungerar likaså för vidaresändning i marknäten som t.ex. via kabel.

Utifrån dessa regler har man organiserat all vidaresändning av grannlands-TV i de nordiska länderna (de mest betydande):

- svT1 och svt2 i Danmark i kabel

- svT1 och svt2 i Norge i kabel (via satellitlänk)

- NRK1 i Sverige i kabel (digitalt i comhems utbud)

- DR1 i kabel i södra Sverige (digitalt i comhems utbud)

- svt Europa i södra Finland via marksändare

- sVT1 och SVT2 i finska Österbotten via marksändare (Bötomberget och Paradisbacken)

- svt1, svt2 och svt Europa i kabel i Finland

- TV4 i kabel i Finland

- svT1 och svt2 (digitala svT 1 och svt2, Barnkanalen och svT24) på Åland samt

- digitala svT1 och svT2, Barnkanalen och svT24 i vissa kabelanläggningar (Åbo kabeltelevisions kabelnät 8,2 €/mån) 
- TV Finland i Sverige via marksändare (Nacka)

- Tv Finland i Sverige i kabel

- NRK1 och TV2 i Danmark i främst kabel

- NRK1, NRK2, DR1, DR2, SVT1 Och SVT2 i Island i kabel

Denna modell anpassar sig också bra för vidaresändning i de digitala marknäten.

Den som är ansvarig för vidaresändningen skaffar vidaresändningslicensen separat via de ursprungliga sändarföretagen eller deras sammanslutningar i de nordiska länderna. I Danmark har sändarföretagen grundat en gemensam organisation (Union of broadcasting organizations in Denmark UBOD), som ger tillståndet för sändarföretagens del. I Sverige och Norge har sändarföretagen använt en motsvarande struktur. I vissa fall har sändarföretagen givit en representationsfullmakt till den lokala upphovsrättsliga förvaltningsorganisationen i grannlandet. Detta är fallet med den finska upphovsrättsorganisationen Kopiosto.

Mottagning av satellitsända grannlandstevekanaler som är avsedda för individuell parabolmottagning (såsom TV Finland, DR 1 och DR2) kräver inga upphovsrättsliga arrangemang i mottagarlandet.

Den nordiska lösningen inspirerade i början av 1990-talet den europeiska modellen i det s.k. satellit- och kabeldirektivet (avtalslösning plus obligatorisk kollektiv förvaltning av rättigheter). Direktivet ledde i sin tur till att man i Danmark började tillämpa avtalslicens i stället för (den ursprungliga) tvångslicensen.

\subsection{En annan möjlighet}

En annan möjlighet att organisera vidaresändningen av grannlands-Tv kunde vara att klarera vidaresändningsrätten redan vid källan, dvs. redan i ursprungslandet hos det ursprungliga sändarföretaget.

I en sådan motsatt s.k. sändarlandslösning görs klareringen av upphovsrättigheterna i sändarlandet av det företag som ursprung- 
ligen sänder programutbudet till allmänheten i sitt eget land. I ett sådant fall kunde sändarföretaget bevilja rätten att vidaresända programutbudet till dem som önskar vidaresända programutbudet $\mathrm{i}$ ett annat land.

Detta lösningsalternativ skulle naturligtvis kräva aktivitet från det ursprungliga sändarföretagets sida. Det skulle betyda att sändarföretaget förhandlar om vidaresändningsrättigheter med sina anställda upphovsmän (eller deras fackföreningar), utomstående filmproducenter och andra innehållsleverantörer samt den eller de upphovsrättsliga kollektivförvaltningsorganisationer som har fullmakt att licensiera vidaresändning utanför ursprungslandet. Om sådana förvaltningsorganisationer inte finns förhandlar sändarföretaget med vidaresändningslandets upphovsrättsorganisation.

För public service-företagens del skulle t.ex. svenska licensbetalare de facto bekosta danska TV-tittares tillgång till svenska TV-program och vice versa. Å andra sidan kan man påpeka att grannlandstittarna troligen representerar ett marginellt tillägg till det egna landets tittare. Detta faktum kan för sin del underlätta lösningar med mycket skäliga ersättningsnivåer eller under vissa förhållanden gratis vidarespridning.

Möjligheterna till en sändarlandslösning varierar i förhållande till om det är inhemskt eller utländskt innehåll som vidaresänds. Kostnadsnivån kan då utformas till en försvårande faktor. Detta kan också ha inverkningar på tillgången till utländskt material på grund av prisfrågor eller bristande vilja att sälja sändningsrättigheter för ett vidare område än sändarlandet. Lösningen är också mycket beroende av sändarföretagets intresse och vilja att organisera mottagningsmöjligheter i andra nordiska länder. Å andra sidan kunde public service-företagen se hela Norden som sin hemmamarknad. Detta skulle naturligtvis underlätta strömlinjeformade lösningar.

Sändarlandslösningen omnämns och kommenteras av EU-kommissionen i tillämpningsrapporten om satellit- och kabeldirektivet.

Information som samlats in för denna utredning tyder för närvarande inte på att utvecklingen på TV-marknaden i Norden skulle ha tagit denna riktning. 


\subsection{Satellit- och kabeldirektivet}

EU:s ministerrådets direktiv om samordning av vissa bestämmelser om upphovsrätten och närstående rättigheter avseende satellitsändningar och vidaresändning via kabel (93/83/EEG) gavs 1993. Direktivets syfte är att harmonisera medlemsstaternas lagstiftning på kärnområdet för denna utredning.

Såsom ovan konstaterats har direktivet - när det gäller vidaresändning via kabel - utformats enligt modell från den nordiska lagstiftningen. Enligt direktivet är de ovan beskrivna avtalslösningarna obligatoriska. Dessutom bör rättigheterna enligt bestämmelserna anskaffas via kollektiva förvaltningsorganisationer. Innehavare av upphovsrättigheter får inte licensiera vidaresändningen individuellt.

Kollektiv rättighetsförvaltning tillämpas inte på sändarföretagen. TV-företagen skall enligt direktivet själva licensiera vidaresändning av sina egna signaler. Detsamma gäller också upphovsrättigheter som företaget har förvärvat.

Det kan vidare påpekas att enligt satellit- och kabeldirektivet kan förvärv av sändningsrättigheter för ursprungliga satellitsändningar ske endast genom avtal. En utvidgad kollektiv licens (avtalslicens, »extended collective licence «) godkänns i direktivet på vissa villkor som ett sätt för rättighetsförvärv, dock inte gällande filmverk.

Kommissionen gav en rapport om genomförandet av direktivet sommaren 2002. I rapporten konstaterades att en inre marknad på det audiovisuella området inte kan utformas utan ett effektivt skydd av upphovsrättigheter och närstående rättigheter. Skyddet stimulerar kreativitet genom att möjliggöra för rättsinnehavare till skyddade verk att till fullo utnyttja sändningsmöjligheterna inom Europa.

Den kollektiva rättighetsförvaltningen har bidragit till ett lättare system för vidaresändning av programutbud i kabelnäten eftersom kabeloperatörerna då har kunnat försäkra sig om att de innehar alla rättigheter till de vidaresända programmen. Eftersom sändarbolagen ofta är både rättsinnehavare och anskaffare av rät- 
tigheter, har deras ställning i direktivet underlättats så att den kollektiva rättighetsförvaltningsorganisationen inte automatiskt och tvingande är den part som representerar dem i förhandlingarna. På grund av detta kan sändarbolaget skaffa sig alla vidaresändningsrättigheter på förhand och därmed vara den enda som förhandlar med kabeloperatören.

Enligt kommissionen finns det en trend att producenterna numera allt oftare säljer rättigheterna till sina program till sändarbolagen under villkor att sändningarna skall sändas krypterade. På detta sätt kan de försäkra sig om att sändningarna inte kan ses utanför nationsgränserna. Dessutom möjliggör modellen att rättsinnehavarna kan sälja rättigheterna till samma program på nytt till en annan medlemsstat.

I kommissionens rapport framförs särskilt synpunkten att möjligheten som direktivet ger har av vissa sändarbolag använts i sin vidaste utsträckning. Detta betyder att bolagen skaffar sig alla rättigheter till ett programutbudsknippe både för ursprunglig sändning och för vidaresändning, vilket betyder att de är de enda förhandlingsparterna i förhållande till kabeloperatörerna.

Kommissionen ansåg $\mathrm{i}$ rapporten att frågorna på området i och med teknikens utveckling och publikens krav kräver ytterligare utredningar i nära samarbete med intressenterna och representanter för de nationella myndigheterna. 


\section{Tekniska lösningsmodeller}

Olika metoder för tillgång till grannlands-Tv beskrivs kort i det följande ur teknisk, ekonomisk och upphovsrättslig synvinkel.

Mottagning på överspillområden

När programutbud sänds i markbundet nätverk kan sändningen ofta ses även på ett annat lands område. S.k. överspillmottagning av analoga sändningar är möjlig för vem som helst som äger en televisionsapparat. Att titta på grannlands-Tv på nordiska public service-kanaler är således möjlig $i$ alla nordiska länder utom Island. Det finns inget behov av tillstånd eller avtal för denna mottagning och den medför inga tilläggskostnader för mottagaren.

Den del av medborgarna i gränstrakterna som på grund av överspillmottagning kan se kanalerna nu, kan se dem även efter övergången till digitala sändningar, eftersom den tekniska standarden för sändningarna är lika och ingen av de nordiska public serviceföretag sänder sina marksändningar krypterade. Tidigare krypterade SVT sina sändningar i det digitala marknätet men slutade med det i början av 2003.

Mottagning av digitala sändningar förutsätter lämplig standardenlig mottagningsutrustning dvs. en digitalbox eller en digital TV, som närmare beskrivits i avsnitt 5.2.

\section{Direktmottagning av satellitsändningar}

Satellitsändningarna har varit digitaliserade redan i en längre tid. Via en satellit kan medborgarna i Norden ta del av utbudet i grannlands-Tv på två sätt: sändningarna kan ses av enskilda hushåll med parabolantenn (DTH) eller så att satellitsändningen först tas emot på marken och sänds sedan vidare till hushållen via kabel eller annan länk. 
Det förstnämnda sättet, dvs. direktmottagning av satellitsändningar kan i upphovsrättslig bemärkelse i princip behandlas som överspillmottagning. Den senare behandlas nedan i samband med vidaresändning via kabel (7.4).

Täckningsområdet för satellitsändningarna har traditionellt varit mycket brett. Det har dock blivit lättare att tekniskt avgränsa mottagningsområdet för satellitkanaler. På ett sådant sätt kan man t.ex. sända programutbud som i praktiken endast syns i de nordiska länderna.

Satellitmottagning av icke-krypterade kanaler är oftast gratis, men mottagningsutrustningen kostar givetvis. Satellitsändningar är trots allt ofta krypterade p.g.a. att sändningsrättigheterna oftast utsträcker sig till ett givet område. Detta betyder att det utöver en särskild mottagningsutrustning behövs ett åtkomstkort (smart card), med hjälp av vilken signalen dekrypteras.

svT Europa och TV Finland är redigerade satellitsända kanaler som består av det inhemska/egenproducerade utbudet från respektive sVT1 och SVT2 och YLE TV1 och YLE TV2 samt MTV3. Dessa kanaler sänds samtidigt med den ursprungliga sändningen. Kanalerna sänds till Europa och sändningarna kan tas emot eftersom de nordiska länderna befinner sig inom mottagningsområdet. De kan ses via Canal Digital eller kabeloperatörerna.

Även vissa hela public service-kanaler sänds via satelliter. De sänds av antingen Telenor, Tele Danmark, Canal Digital eller Viasat. Av dessa kan NRK1 och NRK2 ses endast i Norge, eftersom rättigheterna köpts endast för Norge. DR 1 och DR 2 kan via satellit ses av danska medborgare och andra som har viss anknytning till Danmark. Mottagningen förutsätter ett åtkomstkort, som kan fås av Canal Digital mot en betalning som motsvarar storleken av den danska Tv-licensavgiften (ca 2000 DKK). Man kan också abonnera på kanalerna via Canal Digital i Finland, Sverige och Norge.

Alla satellitsända kanaler har abonnemangsavgifter som sinsemellan varierar något.

Vidaresändning via kabelanläggning genom överspill Ett annat sätt för mottagning av grannlands-TV är vidaresändning och mottagning genom kabelanläggningar. Kabelanläggningarna 
kan variera i storlek - de kan bestå av endast några få hushåll eller ha över 100000 abonnenter. För vidaresändning via kabel behövs ingen koncession av staten.

Tekniskt sett täcker kabelnätverken en stor del av det område på vilket de markbundna sändningarna i respektive land syns, särskilt i Finland och Sverige. I vissa fall har de »byggts upp« för att komplettera de markbundna sändningarna vad gäller public servicekanalerna (särskilt i Finland).

Utbudet i grannlands-Tv sprids vidare ofta just i kabelanläggningar. Vidarespridning via kabel har ansetts vara ett smidigt sätt att nå dem som är intresserade av grannlands-Tv, eftersom det kräver rätt små satsningar för att bygga ett kabelnät.

En markbunden sändning bör sändas vidare i kabelnäten samtidigt med den ursprungliga sändningen. Vidaresändaren betalar upphovsrättsersättningen.

Utöver de nationella s.k. must carry-kanalerna (public servicekanaler eller andra kanaler underställda vidaredistributionsplikt $i$ kabelnäten) bestämmer kabelteveföretagen själva vilka kanaler de sänder i kabelnäten. Kabelteveföretagen har genom åren haft varierande utbudspaket till varierande priser i fråga om grannlandskanaler.

Vid sidan om de digitala marknätverken, som byggs ut i de flesta nordiska länder, utvecklas även system med digitala kabelnätverk och digital satellitdistribution (se också 7.2). Kabeloperatörerna har haft nära samarbete med utvecklarna av det digitala markbundna sändarnätet för att tjänsterna i framtiden skall kunna utnyttjas oberoende av sändningsteknik. Efter övergången till digitala sändningar kommer denna verksamhet att kunna fortsätta precis som förut, men i digitala kabelnätverk.

Ekonomiskt sett kan omvandlingen av hela kabelnätverket till ett digitalt kabelnätverk ses som en stor investering. I Finland har kabeloperatörerna redan så gott som digitaliserat sina nätverk men $i$ andra nordiska länder kan situationen vara en annan. I framtiden kommer digital TV att ge kabeloperatörerna möjligheter att konkurrera med olika tjänster, t.ex. såsom redan nu med snabbare Internetanslutningar och någon typ av bredbands-TV . 


\section{Vidaresändning av satellitsändning via kabelanläggning}

Som redan framkommit kan satellitsändningar ses förutom via parabol även genom att sändningen vidaresänds av kabeloperatören i ett kabelnät. Då måste kabeloperatören skaffa en vidaresändningslicens för den signal och det programinnehåll som sänds vidare. Beroende på vidaresändningstekniken måste operatören eventuellt dessutom inneha medel att dekryptera signalen.

Ett exempel på denna metod är tillgången till svensk TV i Norge. SVT 1 och SVT 2 sänds digitalt och krypterat av Telenor till satelliten där sändningen omvandlas till analog signal för att sändas vidare av kabeloperatörerna, bl.a. UPC i Norge. Även DR 1 sänds vidare $\mathrm{i}$ UPC:s kabelnät i Oslo. UPC tar emot den digitala satellitsignalen och omvandlar den till analog för vidaresändning.

Den norskägda Canal Digital har meddelat att bolagets abonnenter har ökat stadigt $i$ alla de största nordiska länderna under andra hälften av 2003. I slutet av september hade bolaget sammanlagt ca 726000 abonnenter. Av dessa är förstås endast en bråkdel andra abonnenter än de som abonnerar filmkanaler som är baserade på betal-Tv m.m.

Denna form av vidaresändning har goda möjligheter att bli bredare om man kan förhandla om rättigheterna på ett effektivt sätt.

\section{Analog markbunden vidaresändning}

Vidaresändning av markbunden analog signal har använts ganska begränsat för att ge tillgång till grannlands-Tv. Egentligen gäller denna modell bara TV Finland genom Nacka-sändaren i Storstockholm och svT Europa i södra Finland samt svT:s TV-kanaler och TV4 i finska Österbotten.

Denna form av vidaresändning kommer så småningom att övergå till de digitala markbundna näten. Delvis har detta redan skett bl.a. på Åland.

\section{Digital markbunden vidaresändning}

Liksom i det analoga marknätet finns det möjligheter att vidaresända hela kanaler eller redigerade kanaler i de digitala marknäten. 
I vilken utsträckning detta kan ske beror på hur stor kapacitet som reserveras för ändamålet av innehavaren av frekvevensområdet (kanalknippen, MUX) och vilka beslut som fattas om användningen av kapaciteten i respektive nordiska land.

För nuvarande används denna metod endast på Åland fr.o.m. hösten 2003. Vidaresändningen av grannlandskanaler i det digitala marknätet kan fortsätta även efter övergången om man så beslutar. Frågan är tillsvidare öppen om vidaresändningen bör ändras till digital eller inte. För närvarande sker den i de analoga marknäten i Sverige och Finland,

Inga tekniska hinder finns för vidaresändning av markbundna digitala kanaler i grannlandet när det gäller själva sändningen, eftersom standarden är samma i hela Norden och kanalerna inte är krypterade för marksändningarnas del. I vissa fall fungerar MHPbaserade tilläggstjänsterna emellertid inte (t.ex. supertext-Tv) i de andra nordiska länderna förrän standardenliga MHP-digitalboxar tas i bruk.

I fråga om vidaresändning av hela kanaler i det digitala marknätet $\mathrm{i}$ ett grannland måste sändningen säkerligen krypteras på grundval av upphovsrättsfrågorna. Krypterat utbud kan ses endast med hjälp av dekrypteringsutrustning i form av åtkomstkortsystem e.d.

\section{Bredbandslösningar}

Konvergensen mellan television och dator kommer att förstärkas. Digitala mottagningsutrustningar såsom digitalboxar är att se som datamaskiner som utöver normala tillbehör även är utrustade med tuners m.m. Inom en överskådlig framtid är det möjligt att genom snabba kommunikationsförbindelser göra grannlands-TV tillgänglig för alla. Kapaciteten inom telekommunikationsnäten växer fort, och i alla nordiska länder finns det ett politiskt intresse för att ta snabba telekommunikationsförbindelser i allmänt bruk.

Tillsvidare har tekniken på detta område ännu sina begränsningar. En server kan samtidigt betjäna endast ett begränsat antal brukare eller mottagare. Därför kan man att inte med streaming- 
teknik utan stora investeringar nå breda mottagarkretsar, t.ex. hela befolkningen i ett land. Därutöver utgör varje mottagningsförbindelse av en streamingssändning de facto en separat telekommunikationsförbindelse, som har sitt pris.

Beaktansvärt i denna teknik är att streamingsändningar och annat tillgängliggörande över nätverken inte når enbart Norden utan i princip hela världen. Med framtida snabba Internetlösningar kan man inkludera Västnorden - dvs. Island, Färöarna och Grönland - $\mathrm{i}$ den nordiska TV-gemenskapen på ett smidigare sätt.

I dagens läge kan man säga att det finns tre huvudformer för förmedling av programinnehåll i bredband. TV-företagen kan för det första sända sina kanaler $i$ datanäten samtidigt med sändningen $i$ marknäten eller via satellitsändare (samtidig »real time« streaming, »simulcasting (). Det är inte heller uteslutet att innehållet av en Tvkanal kunde sändas över datanäten annan tid än den ursprungliga sändningen (»webcasting«). Ytterligare kan »streaming« i datanäten ske tekniskt skyddat eller på ett öppet sätt (krypterat eller ickekrypterat). Dessa sätt att göra programmen tillgängliga kan upphovsrättsligt jämföras med normal utsändning.

Det finns i princip två interaktiva sätt att göra TV-innehåll tillgängligt för allmänheten. Den första möjligheten är streaming på beställning. I ett sådant fall överförs programinnehållet i realtid till mottagaren. För det andra kan man göra program tillgängliga via en databas där allmänheten ges möjlighet att ladda ner (download) programmen till en minnesenhet. I detta fall sker överföringen snabbt i tätt förpackad (komprimerad) form.

Lösningar som baserar sig på att programmen blir tillgängliga $\mathrm{i}$ datanäten begränsar sig inte enbart till de sändande ländernas territorier. Programmen kan vara tillgängliga överallt dit datanäten utsträcks. Dessa interaktiva sätt att göra program tillgänglig för allmänheten kallas för tillgängliggörande på begäran eller »on demand«. Dessa rättigheter formar även basen för den elektroniska handeln i de öppna datanäten.

Denna streaming förutsätter naturligtvis lösningar som gäller rättigheterna till programinnehållet och signalen. Teknologin är flexibel och erbjuder många möjligheter att underlätta upphovs- 
rättsliga lösningar. Genom t.ex. tekniska skyddsmetoder är det möjligt att utforma mottagarkretsen territoriellt eller t.o.m. från mottagare till mottagare. 


\section{Ställningstaganden och förslag till lösningar}

\subsection{Norden som en TV-hemmamarknad}

Kulturell gemenskap förenar de nordiska länderna. TV-samarbetet har alltid ansetts stärka samhörigheten och den språkliga och kulturella gemenskapen. Det TV-samarbete som utvecklats genom åren mellan de nordiska public service-företagen fungerar relativt väl, också om det inte på långt när motsvarar de många ambitiösa planer som gjorts upp genom åren.

TV-tekniken genomgår snabba förändringar och i synnerhet övergången till digitaltekniken erbjuder många nya möjligheter till ett breddat och utökat samarbete. Public service-företagens och politikernas vilja att utnyttja de nya möjligheterna är avgörande för om digitaltekniken slår igenom även gällande frågan om vi har tillgång till grannlands-Tv eller inte. Distributörerna av programmen, främst innehavarna av kabelnäten, avgör också om det är nordiska eller andra program vi som tittare kan se. Redan nu kunde de flesta nordiska public service-kanalerna göras tillgängliga i de flesta av näten. Oftast prioriteras trots allt andra program än de nordiska $i$ kabelnäten. Många frågar sig därför: Varför syns inte nordisk Tv i nordbornas TV-apparater?

De förslag som läggs fram i detta betänkande kan knappast förverkligas utan en instans som har ansvar för att samordna samarbetet. Därför behövs ett eget sekretariat som övervakas av företrädare både från public service-bolagen och ministerrådet, och som också finansierar sekretariatets verksamhet. Eftersom bolagens primära avsikt oftast är att se till de nationella intressena behövs Nordiska ministerrådets representation för att ständigt 
markera de viktiga gemensamma nordiska intressena. Sekretariatet föreslås förbli mycket litet och bestå av högst en handfull människor.

FÖRSLAG:

1. För att samordna det växande praktiska nordiska TV-samarbetet behövs en permanent enhet som kan byggas upp av Nordvisionssekretariatet och andra redan nu fungerande samarbetsorgan till ett litet permanent sekretariat. Sekretariatets uppgifter är framför allt att stå i kontakt med rättsinnehavarna och deras organisationer och kabelnätens innehavare samt utföra uppdrag som de nordiska public service-företagen eller Nordiska ministerrådet gett sekretariatet. Verksamheten finansieras av företagen och NMR gemensamt. En styrelse bestående av representanter för vart och ett av de nordiska public service-företagen och två representanter från NMR övervakar verksamheten.

\subsection{Finansieringen av verksamheten}

Tillgången till de nordiska TV-programmen i grannländerna kan i huvudsak finansieras på två sätt:

1) Eftersom public service-företagen finansierar sin verksamhet huvudsakligen med offentliga medel är det rimligt att utgå ifrån att mottagandet i grannländerna är avgiftsfritt eller att en eventuell avgift täcker enbart de direkta tilläggskostnaderna. Det här alternativet är helt förenligt med public service-principerna. Då utgår man ifrån att man har en gemensam nordisk public service-hemmamarknad, där även grannlandstittandet ingår i den nationella TV-avgiften.

2) Mottagningen i grannländerna kan ses som en affärsverksamhet som tittarna betalar ett pris för. Priset blir i sådana fall beroende av efterfrågan, av kanalernas konkurrensförmåga i relation till andra internationella kanaler, av i vilket slags paket de nordiska kanalerna placeras i kabelnäten samt av själva priset. Då utgår man ifrån att de som inte betalat Tv-licens, betalar en annan avgift för mottagningen av utbudet. 
Eftersom ekonomin begränsar bolagens rörelseutrymme och eftersom en större spridning skapar merkostnader, är det realistiskt att utgå ifrån att grannlandstittandet förorsakar kostnader som konsumenten i slutändan kommer att stå för.

Alternativ 1, när det gäller finansieringen, är principiellt det mest tilltalande, men om man vill genomföra de flesta förslagen i denna rapport är alternativ 2 förmodligen det mest realistiska.

Om man går in för att följa ett kommersiellt synsätt, måste också public service-företagen kunna lita på att deras program är konkurrenskraftiga. I det avseendet finns det anledning till optimism. Med största säkerhet skulle alla de nordiska grannlandskanalerna kunna konkurrera med t.ex. RAI, TV5, RTL, ARTE och andra som, förtjänstfullt nog redan nu finns i de flesta kabelnät i Norden. Nordbornas förundran över att inte kunna se nordiska TV-kanaler men nog tyska, franska, italienska och andra kanaler, är förståelig, men situationen är inte försvarlig.

Alla förslag som presenteras i den här rapporten kan finansieras enligt något av de två alternativen.

STÄLLNINGSTAGANDE:

2. Om public service-bolagen väljer en kommersiell linje för grannlandstittandet så bör de rimligen också inleda en aktiv marknadsföring av sitt programutbud i grannländerna.

\subsection{Mottagning/spridning av nordiska TV-program}

Mellanperioden före övergången till enbart digitala sändningar De nuvarande lösningarna kan utan hinder fortsätta tills de analoga sändningarna upphör. Dessutom finns det möjligheter att ytterligare utöka sebarhetsområdena, främst genom vidaresändning över kabel och genom ökad direkt satellitmottagning.

Direkt överspill. Mottagning på överspillområdena fortsätter såsom hittills, om inte styrkan eller inriktningen av sändningarna ändras. Upphovsrättsliga hinder föreligger inte med de nuvarande 
reglerna. Tekniska hinder föreligger inte heller för digitala mottagningar, eftersom de nordiska länderna använder samma tekniska standarder för digital TV och inte krypterar kanalerna.

Direkt satellitmottagning. Okrypterade, nordiska, satellitsända Tvkanaler kan som hittills ses direkt. De nordiska, satellitsända, ickekrypterade och redigerade kanalerna är ju faktiskt i första hand avsedda för tittare utanför det egna landets gränser.

Krypterade satellitkanaler. I princip borde alla offentligt finansierade TV-kanaler kunna ses direkt och utan tittaravgift. De upphovsrättsliga avtalen gäller oftast bara inom nationsgränserna och utan särskilda avtal vill rättighetsinnehavarna av programinnehållet ha ersättning för tittandet utanför de avtalade sebarhetsområdena. För att kunna kontrollera merkostnader för sändarbolagen kunde kryptering bli en metod. Då behövs åtkomstkort för att göra programmen sebara. Dessa borde kunna distribueras gratis eller till självkostnadspris till invånare i Eu-länderna, dvs. i praktiken nordbor i sina hemländer eller på annat håll i Europa som vill se nordiska TV-program.

FÖRSLAG:

3. Alla parter som ingår i samarbetet förbereder åtgärder som gör att nor-

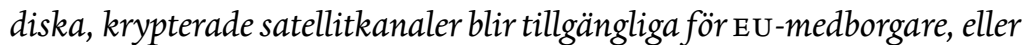
närmast nordbor, gratis eller till självkostnadspris. Åtgärderna bör kunna redovisas senast vid Nordiska rådets session 2005.

Vidaresändning i kabel. Redan nu kunde de nordiska TV-kanalerna vara tillgängliga i vida områden i de nordiska länderna, om kabeldistributörerna skulle önska det. Frånsett de nationella TV-kanalerna, som måste vidarebefordras enligt must carry-principen, bestämmer kabelnätens innehavare själva vilka program som distribueras. Vanligen erbjuder kabelnätets innehavare paket där flera TV-kanaler ingår. Konsumenterna får sedan avgöra vilka paket de prenumererar på. I överraskande liten utsträckning har kabelnätens innehavare tagit med andra nordiska länders kanaler i sitt utbud. Detta kan möjligen bero på att de nordiska public service- 
företagen inte aktivt marknadsför sina kanaler för distribution $\mathrm{i}$ grannländerna. Däremot kan sådana kanaler ingå som inte erbjuder egentliga alternativ till annat existerande utbud.

FÖRSLAG:

4. De nordiska, redigerade, satellitsända kanalerna kan ingå i must carrysystemet när antalet kanaler $i$ kabelnätet överstiger t.ex. 30. Förslaget innebär lagändring och politikerna har därmed makt att avgöra om förslaget blir verklighet eller inte. Rapport om ländernas åtgärder bör kunna ges till Nordiska rådets session hösten 2005.

5. Förhandlingar med kabelnätens innehavare om att inkludera nordiska TV-kanaler i sitt programutbud inleds omedelbart. Det nya sekretariatet för samordning av samarbetet får fullmakt att aktivt marknadsföra Tv-kanalerna i de nordiska grannländerna. Går förslaget igenom får konsumenterna ett mycket större nordiskt programutbud. Dessutom får de nordiska public service-företagen mera pengar, eftersom mera medel flyter in till Nordiska TV-samarbetsfonden, dvs. kabelfonden. Finansieringen av gemensamma programproduktioner ökar därmed också. Kommunikations- och kulturministerierna är garanter för dessa lösningar. Regeringarna bör kunna redovisa åtgärder redan på Nordiska rådets höstsession år 2004.

Specialarrangemangen i Sverige, Finland och på Åland. Med hjälp av särskilda arrangemang, där marksändare används, har man tillgodosett de behov finskspråkiga i Sverige, svenskspråkiga i Finland samt ålänningarna har av mera program på sitt modersmål. Arrangemangen går ut på att den redigerade finländska TV-kanalen kan ses i delar av Sverige, den redigerade svenska kanalen i södra Finland samt svenska public service-kanaler i Österbotten och på Åland. Verksamheten startade utifrån politiska initiativ och är möjlig tack vare samarbetsvilja hos både public service-företagen och organisationerna som bevakar upphovsrätten. 
STÄLLNINGSTAGANDEN:

6. De nuvarande specialarrangemangen bör tryggas också när digitaltekniken tagits i bruk. Eftersom en fortsättning av det gällande systemet inte ställer nya krav på kostnader för upphovsrätt och när de digitaltekniska standarderna är lika i länderna, kan man med samma goda förmåga till samarbete som hittills hålla de populära arrangemangen i kraft också i fortsättningen, ända tills ett eventuellt breddat nordiskt TV-utbud gör dem överflödiga.

Eftersom specialarrangemangen skapats genom beslut av politiker, behövs det snabbt nya tydliga politiska signaler för att garantera verksamheten på sikt.

Åland som banbrytare med digitala marknät. Övergången till digital teknik kan påskyndas genom att inkludera vidaresändning av grannländernas TV-program i ett tidigt skede när digitaltekniken tas i bruk. Åland är härvid en föregångare genom att som första i Norden i oktober 2003 inleda vidaresändningen av SVT:s digitala kanaler i det digitala marknätet på Åland.

\section{Den digitala eran}

TV-programmen kommer att sändas parallellt som analoga och digitala i 3-5 år. Därmed finns det fortfarande tid att planera för hur den ökade sändningskapaciteten som de nordiska public serviceföretagen förfogar över kommer att användas i framtiden. Eftersom det är föga troligt att den offentliga finansieringen stiger $i$ samma takt som kapaciteten inom distributionen ökar, måste samarbetet öka om företagen vill utnyttja sin andel av den nya kapaciteten. I stället för att kapaciteten används till distribution av flera internationella, främst engelskspråkiga kanaler med samma slags innehåll, får vi nu möjligheter att i nordiskt samarbete bygga upp sådana specialkanaler som inget enskilt land ensamt har möjlighet till. Därmed kan utbudet till de nordiska TV-tittarna både breddas och fördjupas.

Övergången till digital teknik behöver inte medföra förändringar när det gäller sebarheten inom överspillområden. Om reglerna ändras för de redigerade, nordiska TV-kanalernas del så att de ingår i 
must carry-systemet och för de krypterade kanalernas del så att de görs tillgängliga för alla nordbor, kan samma regler också gälla inom det digitala systemet.

Den stora förändring som den digitala eran har fört med sig är att ett betydligt större antal kanaler, eller kanalknippen, ryms inom samma frekvensområde. Frågan är hur den nya kapaciteten för distribution skall kunna användas så att mångsidigheten ökar och programurvalet både breddas och fördjupas. Var för sig kan knappast de nordiska public service-företagen med sina nuvarande resurser själva använda alltför mycket av den nya kapaciteten. Alternativen är i huvudsak två: antingen kan man utöka den externa finansieringen, främst genom att öka reklamfinansieringen, eller så ökar man samarbetet med andra public service-företag. Med en ökad reklamfinansiering försvinner skillnaderna till de kommersiella bolagen helt. Därmed är risken mycket stor för att idén om public service-verksamheten flyttar in i historien. Kulturpolitiskt skulle en sådan utveckling vara olycklig. I det ständigt växande antalet kommersiella kanaler sänds nästan enbart samma slag av program, sådana som lockar med lätt underhållning och spänning. Också om public service-företagen i sin programprofil inte lyckats upprätthålla markanta skillnader till de kommersiella företagen, så behövs det en motvikt mot den likriktning de kommersiella företagen står för. Dessa ökar inte längre mångfalden, snarare enfalden.

En annan möjlighet är att de nordiska public service-företagen tillsammans utvecklar nya alternativ till de internationella, specialiserade kanalerna. Det finns goda kulturpolitiska skäl för ett sådant samarbete på flera områden. Den engelskspråkiga dominansen inom barn- och ungdomskulturen är mycket stark. Mera barn- och ungdomsprogram, gjorda utifrån värderingar som gäller i Norden, kunde erbjuda värdefulla och stimulerande alternativ. Det är osannolikt att de nordiska public service-företagen var för sig kan öka resurserna till produktion av barn- och ungdomsprogram, fastän digitaliseringen ger mera utrymme. svT:s projekt med en barnkanal är lovvärd. Sammantaget är produktionen av barn- och ungdomsprogram i Norden så stor att den väl kunde fylla en gemensam kanal. En nordisk TV-kanal för barn och unga 
kunde dessutom erbjuda utrymme för de många unga grupper, som har kulturell aktivitet som sitt stora favoritintresse. Här kunde de för en större publik presentera sina produktioner.

Också andra nordiska specialkanaler på olika områden är tänkbara, t.ex. sport, nyheter, hobbyer, turism, musik och olika slag av arkivmaterial. Filmproduktionen har ökat avsevärt de nordiska länderna de senaste åren och kvaliteten har också stigit. Nordiska filmer i en egen kanal kunde vara ett mycket gott alternativ till de internationella filmkanaler, som redan finns.

FÖRSLAG:

7. Nordiska ministerrådet tar initiativ till förhandlingar med de nordiska public service-företagen om att skapa en nordisk TV-kanal för barn och unga som är tillgänglig $i$ alla nordiska länder. I den skall i första hand ingå de barn- och ungdomsprogram som redan produceras i de nordiska länderna. Beroende på vilka de ekonomiska resurserna är kan dessutom gemensamma, dyrare program produceras som eventuellt kan säljas till andra sändarföretag. En förbättring skulle redan ske om det ökade utrymmet i de nationella kanalerna digitaliseringen ger, delvis fylls av barn och ungdomsprogram från de nordiska grannländerna.

8. Möjligheten att i samarbete skapa andra nordiska specialkanaler som t.ex. en nordisk filmkanal eller en kanal för nordiskt arkivmaterial kunde också övervägas samtidigt. Sådana kanaler kunde vara avgiftsbelagda.

\section{Upphovsrättsliga lösningar}

Upphovsrättsersättningarna för TV-bolagens sändningar bestäms oftast utgående från antalet invånare inom sebarhetsområdet, vilket oftast är detsamma som ett land. Om sebarhetsområdet utvidgas till nya länder, ökar kostnaderna för upphovsrätten betydligt. Trots att antalet TV-kanaler har mångfaldigats ser ändå de överlägset flesta på de nationella kanalerna. Det vore lättare att ta del av de nordiska grannländernas TV-program om man kunde förhandla fram en heltäckande, smidig modell för hur kostnaderna 
för upphovsrätt ersätts i alla former för överföring mellan de nordiska länderna.

\section{STÄLLNINGSTAGANDEN:}

9. Tekniskt är det möjligt att göra nordiska Tv-kanaler i sin helhet sebara i grannländerna genom att sända dem via satellit, och/eller vidaredistribuera dem via kabel samt genom att använda den nya kapacitet som digitaliseringen medför. Begränsande faktorer för överföringen är de territoriella villkoren som rättighetshavarna har ställt och naturligtvis kostnaderna för rättigheterna. Nya tekniskt lätthanterliga system för betal-Tv utvecklas hela tiden som ger konsumenterna stor valfrihet. För att beräkna kostnaderna för bl.a. upphovsrätten behövs en heltäckande smidig modell som kunde basera sig på t.ex. regelbundet utförda tittarmätningar i de nordiska länderna, eller så att kanalerna görs tillgängliga krypterade med hjälp av åtkomstkontroll (åtkomstkort). Nya tekniska lösningar för betal-Tv utvecklas hela tiden som ger både konsumenterna och programbolagen stora valmöjligheter.

10. Både de producerande bolagen och innehavare av upphovsrätten får ekonomisk nytta av att de nordiska Tv-kanalerna mer än nu sprids via kabel. Antalet abonnenter på nordiska Tv-kanaler ökar om de oredigerade, nordiska, kabeldistribuerade kanalerna kan ingå i paket. Priset på paketen kan hållas nere med hjälp av separata avtal mellan alla parter.

11. Det är inte lätt att skapa ett enhetligt system för sådana upphovsrättsliga ersättningar där också behoven av nordiska särlösningar beaktas bl.a. särskilt för att de involverade parterna är så många. I syfte att nå en enhetlig nordisk lösning bör ministerrådet samla parterna till överläggning om hur en nordisk lösning kunde fås till stånd och med beaktande av EU:s regelverk. En första redovisning av förhandlingarna bör kunna ges till Nordiska rådets session hösten 2004. 
Framtida Internet- och bredbandslösningar

Tillgången till nordiska TV-kanaler över datanätet är en realitet inom en överskådlig framtid. Datanätens kapacitet i de nordiska länderna växer snabbt, vilket är en förutsättning för distribution av TV-programmen över nätet. Därmed blir ju också TV-programmen tillgängliga globalt överallt där datanät finns. Via dem kan nordbor även utanför Norden eller utanför satelliternas sebarhetsområden börja ta del av nordiska TV-program. För dem som vill stärka eller bibehålla kontakten med nordisk kultur och nordiska språk är tillgången till TV-program över nätet mycket värdefull.

Många tidningar som till en början höll sin nätversion tillgänglig gratis har börjat ta betalt för den. Prenumeranter av själva tidningen har tillgång till nätversionen till ett nedsatt pris. För att public service-bolagen skall kunna delta i eller till och med leda den tekniska utvecklingen är det rimligt att de som ser TV-programmen över datanäten betalar en avgift för tittandet.

FÖRSLAG:

12. De nordiska public service-företagen kan nå nya tittargrupper med intresse för nordisk kultur och nordiska språk genom att göra TV-kanalerna i sin helhet eller delvis tillgängliga över datanätet (streaming). Programmen kan vara mottagbara i realtid eller sändas över nätet vid en annan tidpunkt. En annan metod är att göra programmen tillgängliga så att de lagras för att kunna laddas ner för senare bruk. Oftast måste de också skyddas för olaglig kopiering, dvs. krypteras. Både streamingen och nerladdningen medför kostnader. Kostnaderna för streamingen täcks av sändarbolagen, kostnaden för nerladdningen i sin tur av konsumenterna.

13. Tekniken ger oss helt nya möjligheter att administrera upphovsrättsersättningar. Det gäller också och i synnerhet program som är tillgängliga över datanätet. De nordiska länderna kan vara bland de första att utveckla tekniska lösningar för samtidig mottagning av sändningar eller för senare sändning och lagring av TV-programmen. 
14. För att snabbt göra TV-program tillgängliga över datanäten är det skäl att börja med de egna programproduktionerna. Till exempel nyheter, aktualitetsprogram, egenproducerade dokumentärer m.m. är programkategorier som ur rättighetsklareringsynpunkt är rätt oproblematiska och kunde därför lämpa sig väl.

\subsection{Nordiskt programsamarbete}

Samarbete inom produktion och utbyte av program

Det praktiska samarbetet mellan de nordiska public service-företagen är rätt omfattande, också om det inte nått upp till de många ambitiösa målen som ställts genom åren.

Nordvisionen är en unik form av samarbete, som omfattar ca 2300 programtimmar per år. Erfarenheterna av samarbetet inom Nordvisionen är värdefulla för det utökade samarbetet inom programproduktionen, som i synnerhet digitaliseringen ger möjlighet till.

Nordiska Film- och TV-fonden (NFTF) finansierar produktion och distribution av film och TV-program. Den är ett värdefullt instrument, särskilt om dess ekonomiska bas kunde förstärkas när digitaliseringen ökar behovet av och möjligheterna till ett mer omfattande nordiskt samarbete. Också inriktningen av stödet bör kunna justeras så att t.ex. nya digitala tjänster och nya programformat kunde få pilotstöd.

Nordiska TV-samarbetsfonden eller "kabelfonden « finansierar sin verksamhet genom de medel som flyter in för vidaresändningsersättningar av public service-bolagens kanaler/program i kabelnäten. Ju större spridning de nordiska Tv-kanalerna får över kabelnäten, desto större resurser har samarbetsfonden att använda för samarbetet.

FÖRSLAG:

15. Nordvisionen, Nordiska Film- och TV-fonden samt Nordiska TV-samarbetsfonden är viktiga instrument i det utökade samarbete digitaliseringen medför. De kan också användas som instru- 
ment när större gemensamma nordiska satsningar planeras. Inom ramen för Nordiska ministerrådets kulturbudget kan man under några år prioritera TV-samarbetet, $i$ syfte att ta tillvara de nya möjligheter digitaliseringen för med sig. Programmässigt kan barn- och ungdomsprogram uppmärksammas alldeles särskilt.

\section{Samarbete på det tekniska området}

NorDig-samarbetet, som inleddes år 1997, har varit framgångsrikt. Godkännandet av gemensamma standarder för digitaltekniken var ett avgörande beslut med tanke på det fortsatta samarbetet. Det tekniska samarbetet måste fortsätta som en integrerad del av det samarbete digitaliseringen skapar utrymme för.

\subsection{Public service - dess framtid och finansiering}

De nordiska ländernas radio- och TV-verksamhet är i en internationell jämförelse av hög kvalitet, i mångt och mycket som en följd av den tillämpning public service-ideologin har haft i Norden. Public service-verksamheten behövs som ett viktigt kulturpolitiskt instrument för att balansera upp den likriktning de privata programföretagen idag står för. En ledande tanke i den nordiska mediepolitiken bör därför vara att bibehålla förutsättningarna för en sund och fördomsfri public service-verksamhet. Den offentliga finansieringen är grunden för hela verksamheten.

I längden kan det vara svårt att bära upp TV-avgiften utgående från innehav av en TV-mottagare, särskilt när allt fler börjar se programmen över datanäten. Avgiften kommer då eventuellt att uppbäras på andra grunder. Förståelsen för en sådan avgift är större ju tydligare public service-kanalernas programprofil avviker från de kommersiella TV-kanalernas profil. När resurserna för produktion av program förblir begränsade medan kapaciteten för distribution ökar avsevärt, är samarbete nödvändigt, särskilt om man vill markera en egen programprofil. Eftersom TV-avgiften godkänns av politiska beslutsfattare har de, tillsammans med public service-företagens ledning ett ansvar för hur genomförandet av uppgiften 
finansieras i framtiden. Också om förslagen till finansiering ligger utanför ramen för den här utredningen, är det angeläget att lyfta fram problemet. En finansiering enligt likartade principer i alla nordiska länder underlättar också det övriga samarbetet.

Public service-bolagen har ett speciellt ansvar för den kulturella mångfalden och för det särpräglade i den egna kulturidentiteten. Idag är deras produktion $i$ alltför hög grad densamma som de kommersiella bolagens. Mera samarbete i planering och produktion kunde bidra till den särprägel som bör höra public service-verksamheten till.

\subsection{Ett par problem}

Två problem har överskuggat arbetet med denna utredning. Dels har det varit omöjligt att mera exakt kvantifiera kostnaderna, inkomsterna eller besparingarna som förslagen medför, dels har ministerrådet som är uppdragsgivare och därmed också regeringarna begränsade möjligheter att förverkliga förslagen. Därmed har också kraven på realism i förslagen ständigt varit närvarande. Finns det vilja hos alla parter så bör också förslagen kunna genomföras.

Ett tredje, men mindre problem är att utvecklingen på området är snabb och att kunskaperna därmed föråldras snabbt.

Genom åren har besvikelserna över tillkortakommandena i det nordiska TV-samarbetet varit stora och många. Den här utredningens syfte är inte att skapa nya, stora förväntningar, utan att peka på betydande möjligheter till samarbete som i synnerhet den nya tekniken för med sig. Beslutsfattarna avgör nu i vilken utsträckning de är beredda att utnyttja dessa nya möjligheter. 


\section{Källförteckning}

\section{BAKGRUNDSMATERIAL}

Nabolands-TV. Rapport fra MR-Kultur till statsministrene. Mulighederne for öket nabolandspredning af nationale tv-programmer i Norden. Mulighederne for oget nordisk tvprogramsamarbeide or programudveksling. 1994.

Samlat material rörande nordiskt radiooch TV-samarbete, Dokument 13, Nordiska rådets 53:e session i Köpenhamn.

Public service i Norden, Del 1, sammanställning och jämförelse av de nordiska ländernas gällande regleringar och regleringsmetoder avseende public service-verksamheten, TemaNord 2001:502, Nordiska ministerrådet, 2001.

Public service i Norden, Del 2, Redogörelse för utvecklingstendenser på radiooch TV-området, aktuella frågeställningar för public service verksamheten och de nordiska public service företagens samarbete, TemaNord 2001:564, Nordiska ministerrådet, 2001.

"Grannlands-TV vid övergången till digitala sändningar « (Marina Österlund-Karinkanta, oktober 2001).

Nordiska rådets rekommendation $32 / 2002$.

Rådets direktiv om »television utan gränser« (89/552/EEG).

Rådets direktiv om samordning av vissa bestämmelser om upphovsrätt och närstående rättigheter avseende satellitsändningar och vidaresändning via kabel (93/83/EEG).

Kommissionens rapport om tillämpningen av satellitdirektivet (ком (2002) 430 slutlig).

Europaparlamentets och rådets direktiv om samhällsomfattande tjänster och användares rättigheter avseende elektroniska kommunikationsnät och kommunikationstjänster (direktiv om samhällsomfattande tjänster) (2002/22/EG).

Meddelande från kommissionen om principer och riktlinjer för gemenskapens audiovisuella politik i den digitala eran (ком(1999) 657-C50144/2000).

EU-parlamentets resolution om meddelande om principer och riktlinjer för gemenskapens audiovisuella politik i den digitala eran (A50209/2000)

Meddelande från kommissionen till rådet, europaparlamentet och europeiska ekonomiska och sociala kommittén om övergången från analoga till digitala sändningar (ком (2003) 541 slutlig).

Amsterdam-fördraget, protokollet om public service - uppgift hos radio- och TV-företag.

Meddelande från kommissionens generaldirektorat för konkurrens- 
ärenden om tillämpningen av statsstödsreglerna om offentliga finansieringen av public service verksamheten (Europeiska gemenskapernas officiella tidning 2001 / C $320 / 5)$ och beslut av kommissionen gällande Frankrike (IP / 03 / $1666,10.12 .2003)$.

Nordiska TV- och filmfonden (NFTF), årsrapporter 2000, 2001 och 2002.
Kommunikationsministeriet Finland; Utredning om finansieringen av public service-verksamheten (2/2001).

Kommunikationsministeriet Finland, Mot digitalåldern (Kohti digitaikaa), Arbetsgruppen för televisionsverksamhet och Rundradion $\mathrm{Ab}$ i Finland 2010 (52/2003).

\section{INFORMATION FRÅN INTERNET}

\begin{tabular}{|c|c|}
\hline \multirow[t]{2}{*}{ www.canaldigital.no } & (även motsvarande nordiska filialer) \\
\hline & - betal-TV-tjänster \\
\hline www.digitv.fi & webbplats för finsk digital TV \\
\hline www.dr.dk & $\mathrm{DR}$ \\
\hline www.etsi.org & Europeisk standardiseringsorgan \\
\hline www.finnpanel.fi/ & Finsk gallupbyrå \\
\hline www.htv.fi & Helsinki televisio \\
\hline www.nordig.org & tekniskt samarbetsforum \\
\hline www.nrk.no & NRK \\
\hline www.ruv.is & RUV \\
\hline www.svt.se & sVT \\
\hline www.satellite-cable.com & Satellitinformation \\
\hline www.sonera.com & TeliaSonera \\
\hline www.vlp.fi & Vasa läns telefon (finskt företag) \\
\hline www.yle.fi & YLE \\
\hline www.1-west.com & Satellitinformation \\
\hline
\end{tabular}


Nordiska ministerrådets och Nordiska rådets publikationer kan beställas hos:

\begin{tabular}{|c|c|c|}
\hline BELGIEN \& LUXEMBOURG & ISLAND & STORBRITANNIEN \\
\hline Jean de Lannoy & Mál og Menning & The Stationery Office \\
\hline Avenue du Roi, 202 & Laugavegi 18, 101 Reykjavik & P.O. Box 276 \\
\hline 1190 Brussels & $\mathrm{Tel}+354(9) 5152500$ & London SW8 5DT \\
\hline Tel +32(0)2 5385169 & Fax $+354(9) 5152505$ & $\mathrm{Tel}+448706005522$ \\
\hline \multirow{2}{*}{$\begin{array}{l}\text { Fax +32(0)2 } 5380841 \\
\text { jean.de.lannoy@euronet.be }\end{array}$} & verslun@mm.is & Fax +448706005533 \\
\hline & KANADA & $\begin{array}{l}\text { customer.services@tso.co.uk } \\
\text { www.tso.co.uk/bookshop }\end{array}$ \\
\hline DANMARK & Renouf Publishing Company Ltd & \\
\hline Svensk-Norsk Bogimport A/S & 5369 Canotek Road, Ottawa & SVERIGE \\
\hline Esplanaden 8 B, 1263 København K & Ontario K1J 9J3 & Fritzes \\
\hline Tel +4533142666 & $\mathrm{Tel}+1(613) 7452665$ & Kundservice, 10647 Stockholm \\
\hline Fax +4533143588 & $\mathrm{Fax}+1(613) 7457660$ & Tel +46 (0)8 6909190 \\
\hline snb@bog.dk & order.dept@renoufbooks.com & Fax $+46(0) 86909191$ \\
\hline www.snbog.dk & www.renoufbooks.com & $\begin{array}{l}\text { order.fritzes@nj.se } \\
\text { www.fritzes.se }\end{array}$ \\
\hline ESTLAND & KINA & \\
\hline Astro Raamatud AS & C N P I E C & TYSKLAND \\
\hline Pärnu mnt 142, 11317 Tallinn & Europe Division & uno-Verlag GmbH \\
\hline Tel +372 6548485 & 16 Gongti East Road & Am Hofgarten 10, 53113 Bonn \\
\hline Fax +3726548475 & P.O. Box 88, Beijing & $\mathrm{Tel}+49(0) 228949020$ \\
\hline \multirow{2}{*}{ book@astro.ee } & $\mathrm{Tel}+86105066$ 688-8 & $\mathrm{Fax}+49(0) 2289490222$ \\
\hline & Fax +86105063101 & info@uno-verlag.de \\
\hline FINLAND & & www.uno-verlag.de \\
\hline Akademiska Bokhandeln & LETTLAND & \\
\hline Рв 128 , Centralgatan 1 & Jana Rozes Gramàtnica & UNGERN \\
\hline 00101 Helsingfors & Kr. Barona iela 5, 1011 Riga & Euro Info Service \\
\hline $\mathrm{Tel}+358912141$ & Tel +371 (0)2 284288 & PO Box 1039,1245 Budapest \\
\hline akatilaus@akateeminen.com & Fax +3717370922 & Tel +36 (1) 3292487 \\
\hline \multirow[t]{2}{*}{ www.akateeminen.com } & & Fax +36 (1) 3492053 \\
\hline & LITAUEN & euroinfo@euroinfo.hu \\
\hline FRANKRIKE & Penki Kontinentai & \\
\hline Librairie LAVOISIER & A. Stulginskio 5, 2001 Vilnius & USA \\
\hline 14, rue de Provigny & $\mathrm{Tel}+370(5) 2664540$ & Bernan \\
\hline 94236 Cachan Cedex & Fax $+370(5) 2664565$ & 4611-F Assembly Drive, \\
\hline Tel +33 (1) 47406700 & books@5ci.lt _ n & Lanham MD 20706-4391 \\
\hline Fax $+33(1) 47406702$ & www.books.lt & $\mathrm{Tel}+1(301) 4597666$ \\
\hline group@lavoisier.fr & & Fax $+1(301) 4590056$ \\
\hline \multirow{2}{*}{ www.lavoisier.fr } & NORGE & query@bernan.com \\
\hline & Akademika A/S & www.bernan.com \\
\hline FÄRÖARNA & Postboks 84 Blindern, 0314 Oslo & \\
\hline H.N. Jacobsens Bókahandil & $\mathrm{Tel}+4722853030$ & ÅLAND \\
\hline Postboks 55, 110 Tórshavn & Fax +4722853080 & Lisco bok- och pappershandel \\
\hline Tel +29831 1036 & bloken@sio.uio.no & Skarpansvägen 25 , Box 8 \\
\hline Fax +298317873 & www.akademika.no & 22101 Mariehamn \\
\hline \multirow[t]{2}{*}{ hnj-bokh@post.olivant.fo } & & $\mathrm{Tel}+358(0) 1817177$ \\
\hline & RUMÄNIEN & Fax $+358(0) 1819771$ \\
\hline HOLLAND & Euromedia s.r.l. & info@lisco.fi \\
\hline De Lindeboom Internationale & Str Dionisie Lupu nr 65 & \\
\hline Publicaties b.v. & 70184 Bucuresti & \\
\hline M.A. de Ruyterstraat $20 \mathrm{~A}$ & $\mathrm{Tel}+4016140664$ & \\
\hline NL-7482 BZ Haaksbergen & Fax +4013129646 & \\
\hline \multicolumn{3}{|l|}{$\mathrm{Tel}+31(0) 535740004$} \\
\hline Fax $+31(0) 535729296$ & & \\
\hline books@delindeboom.com & & \\
\hline www.delindeboom.com & & \\
\hline
\end{tabular}

